\title{
Ubojstva hrvatskih policajaca 2. svibnja 1991. - najava velikosrpske agresije na Hrvatsku
}

\author{
NATKO MARTINIĆ JERČIĆ \\ Hrvatski memorijalno-dokumentacijski centar Domovinskog rata \\ Zagreb, Hrvatska \\ natko.martinic@centardomovinskograta.hr
}

\author{
ANTE NAZOR \\ Hrvatski memorijalno-dokumentacijski centar Domovinskog rata \\ Zagreb, Hrvatska \\ ante.nazor@centardomovinskograta.hr
}

Među datumima koji se u kronologiji Domovinskoga rata ne smiju zanemariti, jer se tada dogodilo nešto što je znatno utjecalo na daljnji tijek događaja u Hrvatskoj, jest 2. svibnja 1991. godine. Toga je dana u Borovu Selu kraj Vukovara u Slavoniji i u Polači kraj Zadra u Dalmaciji iz zasjede ubijeno 13 hrvatskih policajaca, što je znatno pogoršalo već složenu sigurnosnu i političku situaciju u Hrvatskoj. Radi razumijevanja okolnosti („konteksta vremena”) u kojima su počinjena spomenuta ubojstva u radu će se ukratko osvrnuti na uzroke raspada Socijalističke Federativne Republike Jugoslavije i na početak procesa demokratizacije suvremene Republike Hrvatske nakon višestranačkih izbora u travnju i svibnju 1990. te prikazati neke reakcije srpskih ekstremista na spomenuti proces, koje su prethodile ubojstvima 2. svibnja 1991., kao i reakciju hrvatske vlasti i Predsjedništva Socijalističke Federativne Republike Jugoslavije, odnosno vodstva Srbije i Jugoslavenske narodne armije na spomenuti događaj. Naime, nakon toga krvoprolića Predsjedništvo Socijalističke Federativne Republike Jugoslavije na sjednici od 7. do 9. svibnja 1991. pravno je omogućilo, zapravo legaliziralo, uporabu Jugoslavenske narodne armije u Hrvatskoj, službeno radi sprečavanja daljnjih sukoba. Spomenuta ubojstva, koja treba promatrati i u kontekstu pokušaja pobunjenih Srba u Hrvatskoj da izazovu reakciju Jugoslavenske narodne armije i uvođenje izvanrednoga stanja, uvela su Hrvatsku u razdoblje ni rata ni mira. Zapravo je 2. svibnja 1991. postalo jasno da su šanse za mirno rješenje hrvatsko-srpskih prijepora u Hrvatskoj sve manje.

Ključne riječi: srpska pobuna; Domovinski rat; velikosrpska politika; 2. svibnja 1991.; Borovo Selo; Polača; ubojstva hrvatskih policajaca 
Raspad Socijalističke Federativne Republike Jugoslavije, početak procesa demokratizacije hrvatskoga društva i oružana pobuna dijela Srba u Hrvatskoj

Rušenje Berlinskoga zida u studenom 1989. mnogi drže početkom novoga razdoblja europske povijesti. Simbolički gledano, taj događaj predstavlja okončanje „hladnoga rata” i kraj podjele Europe, pa i svijeta, na "Istok” i „Zapad”. Označava i slom totalitarističkih komunističkih režima u istočnoj Europi, koji je započeo početkom osamdesetih godina XX. stoljeća velikom ekonomskom krizom. Na taj su proces znatno utjecale društvene promjene („perestrojka”) i demokratizacija („glasnost”) Sovjetskoga Saveza, započete 1985. dolaskom Mihaila Gorbačova na vlast te svjetske velesile. U travnju 1989. takva politika dovela je do javnoga napuštanja sovjetske („Brežnjevljeve”) doktrine, koja je ograničavala suverenitet socijalističkih država u istočnoj Europi, a potom i do procesa (1990. - 1991.) raspuštanja „Varšavskoga pakta” kao vojno-političke organizacije više komunističkih istočnoeuropskih država. Istodobno je došlo i do razdruživanja Sovjetskoga Saveza i nastajanja novih samostalnih država. Time je omogućeno uvođenje višestranačja u državama dotadašnjega komunističkog bloka. Demokratizaciju društva, iako nije u svim državama provedena mirno, više nije mogla spriječiti ni uporaba sile u režimima s diktatorskim obilježjima. ${ }^{1}$

Proces demokratizacije zahvatio je i Hrvatsku, tada jednu od šest republika Socijalističke Federativne Republike Jugoslavije (SFRJ), u kojoj se inicijative za politički pluralizam javljaju već početkom 1989. godine. Tom procesu pogodovalo je slabljenje utjecaja Sovjetskoga Saveza, čime je Jugoslavija gubila važnost nesvrstane zemlje između sukobljenih blokova. Dakako, na urušavanje Jugoslavije utjecala je i smrt doživotnoga jugoslavenskog predsjednika Josipa Broza Tita (1980.), čija je karizmatičnost, podržana represivnim sustavom, bila jedan od čimbenika njezina održanja. Procesu raspada SFRJ pogodovalo je i nezadovoljstvo njezinih građana pogoršanjem životnoga standarda zbog velike ekonomske krize i inflacije koja je bila sve izraženija od početka osamdesetih godina. ${ }^{2}$ Provedba gospodarskih reformi, temeljenih na tržišnom gospodarstvu i restriktivnoj monetarnoj politici, kako ih je zamislio Ante Marković, koji je u siječnju 1989. postao novi mandatar Saveznoga izvršnog vijeća, zapravo Vlade SFRJ, bez obzira na političku i obećanu financijsku potporu zapadnoeuropskih država, u uvjetima jačanja velikosrpske politike nije bila moguća. ${ }^{3}$

Nakon opisanih velikih političkih promjena u Europi krajem osamdesetih Jugoslavija je kao višenacionalna država početkom devedesetih mogla opstati samo uz uvjet demokratizacije društva i preustrojem u savez država. Stoga se može reći da su ju razbili oni koji su težili centralističkoj politici i jedno-

1 CRAVETTO, GOLDSTEIN, BARIĆ, Povijest, 634-647.

2 ŠETIĆ, Ostvarenje suvremene hrvatske države, 152-153, 158.

3 BARIĆ, Srpska pobuna u Hrvatskoj, 34. 
partijskom monopolu, sprečavajući njezinu demokratizaciju i konfederalni preustroj. ${ }^{4}$ Zapravo je na raspad druge Jugoslavije presudno utjecalo buđenje velikosrpskoga nacionalizma i obnova projekta prema kojem je zapadna granica srpske države u kojoj bi živjeli svi Srbi s područja bivše Jugoslavije bila zamišljena duboko na hrvatskom teritoriju. Potpora institucija u Srbiji nakon dolaska na vlast Slobodana Miloševića takvu projektu, čijom bi realizacijom najveći dio istočnoga, središnjega i jadranskoga područja Hrvatske ušao u sastav nove proširene srpske države, pokazuje koliko su međunacionalni odnosi $\mathrm{u}$ višenacionalnoj Jugoslaviji bili krhki. ${ }^{5}$

Agresivna srpska politika svoj je temeljni cilj - „svi Srbi u jednoj državi” - najprije krajem osamdesetih pokušala ostvariti centralizacijom postojeće države i osiguravanjem političke prevlasti Srba kao najbrojnijega naroda u njoj, a potom oružanom agresijom na Hrvatsku 1991. i Bosnu i Hercegovinu (BiH) 1992. godine. Kada je pod pritiskom Miloševićeve politike Ivan Stambolić sredinom prosinca 1987. napustio dužnost predsjednika Predsjedništva Socijalističke Republike (SR) Srbije, a Miloševićevi ljudi preuzeli sve poluge vlasti, pri čemu će posebno važna biti kontrola nad medijima, u Srbiji su osigurani uvjeti za neometano i agresivnije provođenje velikosrpskoga projekta. Medijska kampanja vođena u medijima u Srbiji koji su bili u državnom vlasništvu znatno je utjecala na kasniju odluku dijela Srba u Hrvatskoj o započinjanju oružane pobune protiv hrvatske vlasti. ${ }^{6}$

Srpski „miting solidarnosti” sa Srbima s Kosova organiziran 9. srpnja 1988. u Novom Sadu bio je uvod u proces nazvan „antibirokratska revolucija” u Vojvodini i Srbiji, a potom i u Crnoj Gori. Pod pritiskom „ulice” i organiziranih „mitingaša” u autonomnim pokrajinama Vojvodini i Kosovu te u SR Crnoj Gori (krajem 1988. i početkom 1989.) vlast su preuzele osobe odane politici novoga „srpskog vođe” Slobodana Miloševića. Odlukom Skupštine SR Srbije 28. ožujka 1989. znatno je ograničena autonomija Vojvodine i Kosova, iako su to de iure ostale pokrajine, a takvo je stanje definirano novim Ustavom Republike Srbije u rujnu 1990., što je bilo u suprotnosti s tadašnjim Ustavom SFRJ iz 1974. godine. ${ }^{7}$ S obzirom na to da su u Predsjedništvo SFRJ (osam članova - šest predstavnika republika i dva autonomnih pokrajina) postavljeni prosrpski orijentirani predstavnici SR Crne Gore, Vojvodine i Kosova, Milošević je osigurao kontrolu nad polovicom njegovih članova, a Srbija dominaciju u državnom predsjedništvu. ${ }^{8}$ Istodobno je na valu mitinga, prozvanih „doga-

${ }_{4}$ NOBILO, Hrvatski feniks, 16-18.

5 JOVIĆ, Poslednji dani SFRJ, 193.

6 ŽUNEC, Goli život, sv. II, 569 (bilj. 1107).

7 RADELIĆ et al., Stvaranje hrvatske države, 95.

8 Poznati odvjetnik iz Beograda Srđa Popović u svojoj je knjizi zaključio da je u procesu protiv Slobodana Miloševića dokazana „njegova odlučujuća uloga u raspadu SFRJ i započinjanju ratova”, da se „jasno vidi kako se Milošević dokopao odlučujućeg uticaja i kontrole nad JNA i njenim vrhovnim komandantom, Predsjedništvom SFRJ”, da je dokazano da je „preko JNA i srpske policije on uspeo da ostvari i kontrolu nad paravojnim formacijama, kao i nad Vojskom Republike Srpske, koju je formirao, naoružao i plaćao", te da je iz izvora i uvida u kronologiju 
đanja naroda”, ohrabren masovnom potporom srpskoga naroda, kojemu je obećao rješavanje pitanja Kosova, okupljenom mnoštvu Srba na Kosovu polju kod Prištine na Vidovdan 28. lipnja 1989. poručio da u borbi za srpske interese nisu isključene ni "oružane bitke". ${ }^{9}$ U skladu s velikosrpskom politikom iz Beograda, početkom 1989. i tijekom 1990. mitinzi Miloševićevih pristaša proširili su se na Hrvatsku. Organizirani na područjima na kojima su Srbi živjeli u znatnijem broju, isprovocirali su reakciju Hrvata, što je pogoršalo srpskohrvatske međunacionalne odnose. ${ }^{10}$

U siječnju 1990. propao je pokušaj srbijanskoga vodstva da sazivanjem 14 . izvanrednoga kongresa Saveza komunista Jugoslavije u Beogradu nametne svoju opciju centralizirane Partije, što je bio preduvjet i za centralizaciju države. Zbog odbijanja svih prijedloga slovenskih predstavnika te isključivog i provokativnog ponašanja većinskih, prosrpskih zastupnika kongres je 22. siječnja napustila slovenska, a potom i hrvatska delegacija. ${ }^{11}$ Otvoreno raslojavanje Saveza komunista Jugoslavije, uz Jugoslavensku narodnu armiju (JNA), nakon smrti Josipa Broza Tita, najvažnijega kohezivnog čimbenika druge Jugoslavije, bilo je jasan znak da je proces raspada te države već otpočeo i da se demokratizacija društva u Sloveniji i Hrvatskoj ne može zaustaviti.

Uslijedili su intenzivni razgovori srbijanskoga vodstva s generalima JNA Veljkom Kadijevićem i Blagojem Adžićem o sljedećim potezima i pojačanom djelovanju JNA. Sadržaj dnevnika Borisava Jovića, jednoga od najbližih suradnika tadašnjega svesrpskog vođe Slobodana Miloševića i predstavnika Srbije u Predsjedništvu SFRJ (od 15. svibnja 1990. i njegov predsjednik), pokazuje razmjere jugoslavenske krize početkom 1990. te potvrđuje suradnju srbijanskoga i vojnoga vrha mimo kolektivnoga Predsjedništva SFRJ, kao i sazrijevanje njihove odluke o ratnoj opciji i ulogu JNA u tom procesu. ${ }^{12}$ Prema sadržaju Jovi-

događaja „jasno da je prvi separatistički ustav donela Srbija, da je Milošević sistematski rušio sve savezne institucije, da je tajno organizovao oružanu pobunu u Hrvatskoj, da je amputirao Sloveniju da bi prvo paralisao, a potom osvojio Predsedništvo, te da je na kraju preko Jovića kontrolisao Predsedništvo, a preko Predsedništva Armiju” (POPOVIĆ, One gorke suze posle, 117, 120).

9 „Govor Slobodana Miloševića, predsednika Predsedništva SR Srbije, na Gazimestanu”, NIN, Beograd, 2. 7. 1989., 6-7.

10 MARIJAN, „'Događanja naroda’ u Kninu 1989., 440-446; Republika Hrvatska, Ministarstvo unutarnjih poslova (dopis br. 511-01-41-22093-1990.), Informacija o dogadajima u nemirima obuhvaćenim općinama Republike Hrvatske, 7. studenog 1990. (dalje: Informacija 1990.).

${ }_{11}$ MARIJAN, Hrvatska 1989. - 1992., 119-124; RADELIĆ et al., Stvaranje hrvatske države, 91.

12 „Dana 26. januara, nakon što su delegati Slovenije otišli sa Kongresa Saveza komunista, razgovarao sam sa Kadijevićem i složili smo se da se u Sloveniji i na Kosovu mora pojačavati vojno prisustvo. Pribojavali smo se da će separatisti dobiti polet usled otvorene slovenačke podrške na XIV kongresu Saveza komunista. Složili smo se da su ključni zadaci Armije sledeći: ne dozvoliti raspad zemlje, ne dozvoliti ničije nasilno ili protivustavno otcepljenje i bratoubilački rat, a to može u kritičnoj situaciji da spreči Armija, ako bude na to pripremljena i odgovarajuće raspoređena. Mora biti spremna na akciju u roku od nekoliko sati, na svim terenima. [...] Posle današnje sednice Predsjedništva SFRJ [13. veljače 1990., op. a.], Milošević i ostali su došli kod mene u kancelariju. Milošević kaže: 'Biće rata, bogami.' 'Nećemo dati, bogami', uzvraćam ja. 'Dosta smo mi ratovali i ginuli u dva svetska rata. Sada ćemo rat svakako da izbegnemo!' 'Neće biti rata onakvog kakav bi oni hteli' - dodaje Veljko - 
ćeva dnevnika (26. ožujka 1990.) može se zaključiti i da je krajem ožujka 1990. srbijansko vodstvo bilo uvjereno da se raspad Jugoslavije ne može zaustaviti te da je rat sasvim izvjestan na područjima na kojima žive Srbi u Hrvatskoj i $\mathrm{BiH}$, stoga je pristupilo izradi novoga ustava Srbije za novu samostalnu srpsku državu, koju treba uspostaviti. ${ }^{13}$

U Hrvatskoj se razumnija struja u komunističkom vodstvu krajem 1989. odlučila za uvođenje višestranačja, a početkom 1990. provedene su izmjene u zakonu potrebne za legaliziranje novih političkih stranaka i održavanje neposrednih, tajnih, višestranačkih izbora u travnju i početkom svibnja iste godine. Uvjerljivi pobjednik izbora bila je Hrvatska demokratska zajednica (HDZ), predvođena dr. Franjom Tuđmanom, bivšim generalom JNA, a potom hrvatskim disidentom i povjesničarom, kojega su komunističke vlasti zatvarale i kažnjavale vremenskom kaznom zabrane javnoga istupanja. Na rezultate izbora u Hrvatskoj, u dogovoru sa srbijanskim dužnosnicima, vojne vlasti SFRJ odmah su reagirale oduzimanjem gotovo cjelokupnoga naoružanja hrvatske Teritorijalne obrane prije negoli je održana konstitutivna sjednica novoizabranoga hrvatskog Sabora. ${ }^{14}$ Razoružavši Hrvatsku, JNA je unaprijed i smišljeno osigurala vojnu nadmoć u slučaju oružanoga raspleta političke krize u Jugoslaviji.

Usprkos takvoj prijetnji, 30. svibnja 1990. održana je konstituirajuća sjednica novoga, višestranačkog Sabora SR Hrvatske, na kojoj je u skladu s rezultatima izbora predsjednik HDZ-a Franjo Tuđman postao predsjednik Predsjedništva SR Hrvatske, odnosno prvi predsjednik demokratske Hrvatske, a HDZ je preuzeo vlast i postao vodeća stranka u državi. Konstituirajuću sjedni-

'ali će biti onakav kakav mora, a to je da im ne dozvolimo da nas tuku"' (JOVIĆ, Poslednji dani SFRJ, 93-94, 108).

13 „Sastanak 'koordinacije' u SR Srbiji. Učestvuju svi čelni funkcioneri (Republika, Savez komunista, SSRN, Sindikat, Komora, Grad). Razmenujemo mišljenja o ključnim pitanjima političke situacije i zajedničke orijentacije za rad. [...] Ocenjujemo da se ostvaruje proces raspadanja Jugoslavije na sličan način kao što se to desio sa Savezom komunista Jugoslavije. Izgleda nam nezaustavljiv. Srbija će voditi iskrenu politiku opstanka federativne Jugoslavije, ali će se spremiti da živi i bez Jugoslavije. U eventualnom raspadu zemlje, Srbija računa na jedinstvo sa Crnom Gorom. Makedoniju nećemo da molimo. [...] Naš je cilj da izbegnemo krvoproliće, da uspostavimo granicu unutar koje se neće ratovati. Van te granice rat se neće moći izbeći, jer Bosna i Hercegovina neće moći da opstane kao država, a bitka oko teritorije bez krvi teško je zamisliva. Srbija neće pristati na konfederaciju. [...] Inače, procenujemo da će se Jugoslavija verovatno raspasti već vidljivom tehnologijom: republike će jedna po jedna (počev od Slovenije) doneti nove ustave, koji će biti u sukobu sa važećim ustavom Jugoslavije, a o novom ustavu Jugoslavije neće se postići suglasnost. Na taj način Jugoslavija će nestati, pa će se postaviti pitanje konfederacije do koje neće doći, nego će nastati sukob usled neslaganja srpskog naroda u Hrvatskoj i u BiH sa takvom nacionalnom pozicijom (odvajanja od matice i pretvaranja u nacionalnu manjinu). Srbija je odlučila da odmah pristupi izradi novog ustava koji će biti sposoban da pokrije novu samostalnu srpsku državu. Sreća je što je ustavnim amandmanima na Ustav SR Srbije 28. II. [zapravo III., op. a.] 1989. uspostavljena državna nadležnost SR Srbije na celoj teritoriji" (JOVIĆ, Poslednji dani SFRJ, 131-132).

14 JOVIĆ, Poslednji dani SFRJ, 146; RUPIĆ, Dokumenti: Oružana pobuna Srba u Hrvats$k o j$, „Zapovijed načelnika Generalštaba OS SFRJ komandama vojnih oblasti za oduzimanje naoružanja TO i način čuvanja istog”, 19-20. 
cu bojkotirala je Srpska demokratska stranka (SDS), koja je inscenirani napad na jednoga njezina aktivista u Benkovcu iskoristila kao razlog za suspenziju odnosa s Hrvatskim saborom. ${ }^{15}$

Odmah potom, 27. lipnja 1990., Skupština općine Knin donijela je „Odluku o osnivanju i konstituiranju Zajednice općina Sjeverne Dalmacije i Like”, čime je dio srpskih političara u Hrvatskoj započeo proces protuustavnoga djelovanja i prekrajanja upravno-teritorijalnoga ustrojstva SR Hrvatske. ${ }^{16}$ Mjesec dana poslije, 25. srpnja 1990., na mitingu Srba u Srbu u Hrvatskoj osnovano je Srpsko nacionalno vijeće i donesena Deklaracija o suverenosti $i$ autonomiji Srba u Hrvatskoj te najavljen referendum za autonomiju Srba u Hrvatskoj. ${ }^{17}$ Istoga dana prihvaćeni su amandmani na Ustav SR Hrvatske kojima je, među ostalim, iz naziva države uklonjen pridjev „socijalistička”, umjesto zvijezde petokrake na hrvatsku zastavu vraćen je „povijesni” hrvatski grb sa 25 crvenih i bijelih (kvadratnih) polja, a promijenjeni su i dotadašnji nazivi tijela vlasti i dužnosti. ${ }^{18}$

Protuustavne političke odluke vodstva pobunjenih Srba pratilo je narušavanje javnoga reda i mira, ugrožavanje sigurnosti građana, razbojstva, ali i terorističko djelovanje srpskih ekstremista, među kojima su bile i osobe ubačene iz Srbije, koje je posebno pojačano u drugoj polovini 1990. godine. U gotovo svim mjesnim zajednicama s većinskim srpskim pučanstvom („u Kninskoj krajini, Lici, te na Kordunu i Baniji”) zabilježeni su primjeri ponašanja s elementima oružane pobune, radnji koje imaju sva obilježja teških kaznenih djela - krađa, razbojstava, ugrožavanja sigurnosti, pa sve do terorističkih akata (diverzije na gospodarskim objektima i cjelokupnoj infrastrukturi, posebice ugrožavanje sigurnosti prometa miniranjem prometnica, krađa oružja iz skladišta JNA, oružani napadi na hrvatske policajce i civile, presretanje vozila te zadržavanje i zlostavljanje građana itd.). ${ }^{19}$

\footnotetext{
${ }^{15}$ Među brojnim dezinformacijama o navodnom stradanju i ugrožavanju Srba u Hrvatskoj posebnu medijsku pozornost privukao je „slučaj Mlinar”. Naime, 18. svibnja 1990. tada 23-godišnji Miroslav Mlinar, predsjednik mjesnoga ogranka SDS-a, pronađen je ranjen u Benkovcu. Srbi su odmah optužili Hrvate kao „vekovnu” prijetnju, tj. ustaše i koljače. Međutim, slučaj je dospio u medije, a potom se ispostavilo da je Mlinar sam sebe ozlijedio (Informacija 1990., 1). Koliko je taj inscenirani slučaj eksploatiran u srbijanskim medijima u njihovoj beskrupuloznoj ratno-huškačkoj kampanji pokazuju naslovi objavljeni u srpskom tisku: „Dijalog iz zasede”, Novosti (Beograd), 21. 5. 1990.; „Ružan, bezdušan, ustaški čin”, Politika (Beograd), 21. 5. 1990.; „Agresija koja upućuje na ustaštvo”, Politika, 22. 5. 1990.; „Atak na ceo srpski narod”, Politika, 22. 5. 1990.; "Nepodnošljiva lakoća srpskih ratnika”, Politika, 22. 5. 1990.; „Napad na srce”, Duga (Beograd), 8. 6. 1990.; „Moja tragedija je tragedija srpskog naroda”, Politika, 17. 6. 1990. itd.

${ }_{16}$ Službeni vjesnik općina Drniš, Knin i Šibenik, Šibenik, 12 (1990); Službeni vjesnik Like, 12 (1990).

17 „Izvješće u povodu inicijative Vlade Republike Hrvatske, klasa: 004-01/02-02/12, ur. broj: 5030109-02-2 od 10. listopada 2002. godine”, Ustavni sud Republike Hrvatske (predsjednik Suda, dr. sc. Smiljko Sokol), broj: U-X-2271/2002, Zagreb, 12. studenog 2002., 11 (dalje: Izvješće - Ustavni sud RH 2002.).

${ }^{18}$ Narodne novine (Zagreb), 31 (1991), Amandman LXVI.

${ }_{19}$ MARIJAN, Hrvatska 1989. - 1992., 468-473, 494-495; Republika Hrvatska, Ministarstvo
} 
Zapisi iz Jovićeva dnevnika također svjedoče da je SDS u Hrvatskoj, odnosno vodstvo pobunjenih Srba svojim zahtjevima prema hrvatskom vodstvu zapravo samo kupovalo vrijeme dok se srbijansko vodstvo u Beogradu i JNA ne dogovore o načinu realizacije cilja „svi Srbi u jednoj državi” i granicama takve države. Tome u prilog posebno govori Jovićev zapis razgovora s Dobricom Ćosićem od 11. rujna 1990. godine:

„Nema više ni jednog ozbiljnog razloga za postojanje Jugoslavije. [...] Dakle, nema sile koja nas može ujediniti. U tim okolnostima ostalo je otvoreno pitanje sudbine Srba i Srbije u raspadu Jugoslavije kao glavno političko pitanje. Bar za nas. [...] Sada se radi etnička karta srpskoga prostora, naročito u Bosni i Hercegovini i Hrvatskoj, da se jasno prikaže teritorija gde su Srbi u većini; od Šibenika, preko Like, Bosanske krajine, pored Save do Bijeljine svuda su Srbi u većini. U centru Bosne su Muslimani. Srbi presijecaju i Sandžak pored Drine, pa se Muslimani ne mogu ujediniti. To je budući prostor Srbije." ${ }^{20}$

Uz podršku iz Srbije i prikrivenu potporu JNA, vodstvo pobunjenih Srba pripremalo je oružanu pobunu. Tako su 17. kolovoza 1990. naoružani Srbi zaposjeli prometnice u okolici Knina te balvanima i kamenjem zapriječili glavne cestovne pravce iz unutrašnjosti Hrvatske prema Dalmaciji, odnosno hrvatskom priobalnom području. Pokušaj hrvatske policije da uspostavi red i osigura mir na tom području spriječila je JNA. ${ }^{21}$ Spomenuti događaj, prozvan „balvan-revolucijom”, bio je početak oružane pobune dijela Srba na prometno-geografski krucijalnom prostoru, koji je unutrašnjost Hrvatske povezivao s njezinim obalnim područjem. ${ }^{22}$

Potom su kod Obrovca u studenome 1990. „oko 2 sata u noći između 22. i 23. studenoga, na križanju ceste Obrovac-Benkovac-Žegar” srpski teroristi „pucali na patrolu Policijske postaje Benkovac” te ubili policajca Gorana Alavanju i ranili policajca Stevana Bukaricu, svoje sunarodnjake, koji su se nakon početka oružane pobune u kolovozu iz Biograda i Zadra, gdje su bili na dužnosti, premjestili u Sekretarijat unutrašnjih poslova (SUP) Benkovac, na područje koje će vodstvo pobunjenih Srba nedugo potom proglasiti „Srpskom autonomnom oblasti Krajina". 23 To je područje već tada de facto bilo izvan kontrole Ministarstva unutarnjih poslova Republike Hrvatske (MUP RH) i hrvatske vlasti. Zatim je u Dvoru na Uni 29. studenog 1990. uhićeno nekoliko osoba iz Srbije koje su naoružane obilazile Hrvatsku radi osnivanja „Ratnoga savjeta" Srba u Hrvatskoj. Među njima je bio i Željko Ražnatović Arkan, jedan od najpoznatijih srpskih kriminalaca i vođa „Delija”, navijačke skupine srpskoga nogometnoga kluba „Crvena zvezda”. Spomenute radnje poticalo je srbijansko

informiranja, Dossier: Knin (veljača 1990 / veljača 1991.), Zagreb, veljača 1991., 192 (dalje: Dossier: Knin); Večernji list (Zagreb), 24. 11. 1990.

${ }^{20}$ JOVIĆ, Poslednji dani SFRJ, 193.

${ }^{21}$ Više o svemu vidi u: MARIJAN, Slom Titove armije, 228-230.

${ }^{22}$ RADELIĆ et al., Stvaranje hrvatske države, 94.

${ }^{23}$ Dossier: Knin, 192; Večernji list, 24. 11. 1990. O okolnostima ubojstva Gorana Alavanje opširnije u: VUČUR, „Pogibija Gorana Alavanje”, 587-609. 
vodstvo, a za njihovu organizaciju i provedbu bile su zadužene srbijanske sigurnosne službe. ${ }^{24}$

Bar približnu sliku o djelovanju srpskih ekstremista od srpnja do studenoga 1990. pruža Informacija o događajima u nemirima obuhvaćenim općinama Republike Hrvatske (dalje: Informacija), koju je 7. studenog 1990. ministar unutarnjih poslova RH Josip Boljkovac dostavio predsjedavajućem delegacije Sabora RH u Vijeću republika i pokrajina Skupštine SFRJ Đuri Vidmaroviću radi rasprave koja se trebala provesti u Skupštini SFRJ na temu „Aktualna političko-sigurnosna situacija i aktivnosti Predsjedništva SFRJ za izlazak iz ustavne krize u Jugoslaviji”. U Informaciji je stajalo da su „uspostavom nove demokratski izabrane vlasti Republike Hrvatske eskalirale aktivnosti usmjerene na destabilizaciju političke i sigurnosne situacije, odnosno na protuustavnu promjenu poretka i ugrožavanje teritorijalnog integriteta Republike". Naglašeno je da se „aktivnost na destabilizaciji Republike Hrvatske s namjerom izazivanja ili raspirivanja nacionalne mržnje, razdora ili netrpeljivosti između hrvatskog i srpskog naroda, odvija u kontinuitetu od proslave 600. godišnjice Kosovske bitke u Kosovu kod Knina (1989. g.)”, da se ista aktivnost „nastavlja mitingom na Petrovoj gori te skupom u Srbu i formiranjem Srpskog nacionalnog vijeća, da bi, počevši od 17. kolovoza ove godine nadalje, poprimila posve konkretne neustavne i nezakonite - kriminalne oblike, kao što su diverzije i sabotaže, pozivanje i sudjelovanje u oružanoj pobuni i terorizam".

Spominje se i da „ک̌ira politička zbivanja u nas [u Hrvatskoj, op. a.] unatrag godinu i pol dana pa sve do najnovijih zbivanja, ali i saznanja Službe o organiziranoj djelatnosti na opstrukciji legalnih vlasti Hrvatske i stvaranju međunacionalnog raskola, upućuju na činjenicu da se destabilizacija Hrvatske događa prema utvrđenom scenariju koji se materijalizira dnevno od verbalnih do oružanih aktivnosti i manifestacija". Informacija pokazuje i da je primjetno da se „već od višestranačkih izbora do formiranja novih organa vlasti i Sabora odvija žestoki propagandni rat, $s$ ciljem da se dokaže kako je nova vlast izrazito antisrpski nastrojena te će ukinuti sva prava srpskom narodu u Hrvatskoj", a da „tu ulogu preuzima Srpska demokratska stranka i njezini čelnici koji već politiziranjem slučaja Mlinar jasno naznačuju da će u budućnosti svim sredstvima pokušati rušiti ustavni poredak". 25

U takvim okolnostima Hrvatski sabor donio je 22. prosinca 1990. odluku o proglašenju novoga hrvatskog Ustava, kojim je Hrvatska određena kao jedinstvena i nedjeljiva, demokratska i socijalna država. Njegovim odredbama promiču se ljudska prava i slobode, odnosno ravnopravnost svih građana pred zakonom, te višestranačka demokracija, tržišno gospodarstvo i pravo privatnoga vlasništva. ${ }^{26}$

\footnotetext{
${ }^{24}$ MARIJAN, Hrvatska 1989. - 1992., 410-419, 473.

${ }^{25}$ Informacija 1990., 1.

${ }^{26}$ Narodne novine, 56 (1990).
} 
Dan prije, 21. prosinca 1990., pobunjeni Srbi u Kninu su proglasili Srpsku autonomnu oblast Krajinu (SAO Krajina) i donijeli njezin Statut, a obuhvatila je općine sa znatnim udjelom građana srpske narodnosti u središnjim dijelovima Hrvatske (Dalmacija, Lika, Banovina i Kordun). U Dalmaciji je ta paradržavna tvorevina obuhvatila sjevernodalmatinske općine Knin, Obrovac i Benkovac, a početkom 1991. na jugu se širila na područje općina Drniš, Šibenik i Sinj. ${ }^{27}$ Sadržaj Statuta SAO Krajine pokazuje da je, u slučaju preustroja SFRJ $\mathrm{u}$ savez suverenih država ili osamostaljenja $\mathrm{RH}$, vodstvo pobunjenih Srba $\mathrm{u}$ Hrvatskoj namjeravalo Krajinu pripojiti Srbiji smatrajući ju „historijskim i etničkim srpskim prostorom" ${ }^{28}$ Takve oblasti potom su proglašene i u istočnoj Slavoniji (veljača 1991.) i u zapadnoj Slavoniji (kolovoz 1991.). Dakako, hrvatski Ustavni sud proglasio ih je ilegalnim, protuustavnim i nevažećim. ${ }^{29}$

Početak 1991. donio je nove prijetnje hrvatskom vodstvu i nastavak protuustavnih aktivnosti pobunjenih Srba u Hrvatskoj. Formiranjem SUP-a SAO Krajine 4. siječnja 1991. vodstvo SAO Krajine u Kninu odlučilo je da na tom području prestaju vrijediti ingerencije MUP-a RH. ${ }^{30}$ Tom odlukom, kojom su policijske postaje u Kninu, Obrovcu, Benkovcu, Gračacu, Korenici, Donjem Lapcu, Dvoru na Uni, Vojniću, Glini i Hrvatskoj Kostajnici otkazale poslušnost MUP-u RH i ušle u sastav krajinskoga SUP-a SAO Krajine, samo je institucionalizirano stanje pobune koje je trajalo već od ljeta 1990., kada je dio policajaca srpske nacionalnosti otkazao poslušnost MUP-u RH u Zagrebu. ${ }^{31}$ Istodobno je JNA, na temelju Naredbe Predsjedništva SFRJ od 9. siječnja 1991. da se u roku od deset dana moraju „razoružati i raspustiti sve oružane formacije, koje nisu u sastavu jedinstvenih oružanih snaga SFRJ ili organa unutrašnjih poslova i čija organizacija nije utvrđena u skladu sa saveznim propisima", ${ }^{32}$ planirala uporabiti silu i spriječiti jačanje hrvatskih policijskih snaga iako se ono provodilo u skladu s republičkim i saveznim zakonima. Činilo se da je uvođenje izvanrednoga stanja u Jugoslaviji u siječnju 1991. neizbježno, tim više jer je pozornost svijeta tada bila usmjerena prema savezničkoj vojnoj intervenciji u Iraku, pokrenutoj zbog iračke okupacije Kuvajta. Dakako, uvođenjem izvanrednoga stanja u pitanje bi bio doveden opstanak demokratski izabrane hrvatske vlasti. No, razgovorima u Beogradu 25. siječnja 1991., posebice na sjednici Predsjedništva SFRJ, hrvatsko vodstvo uspjelo je spriječiti intervenciju JNA. ${ }^{33}$

\footnotetext{
${ }^{27}$ ĐURIĆ MIŠINA, Republika Srpska Krajina, 16; BARIĆ, Srpska pobuna u Hrvatskoj, 77-81, 95-96.

${ }^{28}$ Izvješće - Ustavni sud RH 2002., 12 (bilj. 28); RUPIĆ, Dokumenti: Dokumenti institucija pobunjenih Srba, 120-124.

${ }^{29}$ Izvješće - Ustavni sud RH 2002., 12.

30 „Odluka o osnivanju Sekretarijata za unutrašnje poslove SAO Krajina i Rešenje o imenovanju sekretara za unutrašnje poslove SAO Krajina”; Izvješće - Ustavni sud RH 2002., 13.

${ }^{31}$ BARIĆ, „Osnutak i razvoj službe unutrašnjih poslova autonomnih oblasti u Hrvatskoj”, 77.

32 „Rasformirati sve neregularne oružane sastave”, Narodna armija (Beograd), 17. 1. 1991., 4.

${ }^{33}$ O tim zbivanjima detaljno u: MARIJAN, Hrvatska 1989. - 1992., 476-484.
} 
Čekajući reakciju JNA, vodstvo pobunjenih Srba u Hrvatskoj nastavilo je razmatrati opcije pripajanja hrvatskoga teritorija Srbiji. Očigledno u kontaktu sa srbijanskim vodstvom, ni tjedan dana nakon Miloševićeva zahtjeva da JNA „pokrije 'srpska' područja u Hrvatskoj”, predsjednik SDS-a, istaknuti srpski intelektualac i akademik Jovan Rašković, poručio je 29. siječnja 1991. članstvu svoje stranke da je „nacionalni pokret srpskog naroda u Hrvatskoj pokret za nacionalnu ravnopravnost, građanska prava i demokratsku rezidualnu i saveznu Jugoslaviju, ali da kao neke druge mogućnosti, koje će postati aktuelne za, najkasnije, nekoliko mjeseci, ostaju: samostalna Srbija, srpska država Krajina kao dio ili autonomna pokrajina Srbije ili, konačno, etnička Srbija koju mogu zvati zastarjelom krilaticom ili podvaljivačkim imenom velike Srbije". ${ }^{34}$

Nakon što su 1. ožujka 1991. pobunjeni policajci srpske narodnosti u policijskoj postaji u Pakracu, u zapadnoj Slavoniji, razoružali i zarobili svoje kolege hrvatske nacionalnosti s ciljem pripajanja općine Pakrac SAO Krajini, 2. ožujka dogodio se prvi oružani sukob između srpskih terorista i hrvatske policije u Domovinskom ratu. U sukobu nije bilo smrtno stradalih, iako je iz vatrenoga oružja ranjeno nekoliko hrvatskih policajaca. Potom su 31. ožujka 1991., na sam Uskrs, u Nacionalnom parku Plitvička jezera srpski teroristi iz zasjede napali hrvatske policajce. Tom prilikom ubijen je hrvatski policajac Josip Jović - prvi poginuli pripadnik sigurnosno-obrambenoga sustava $\mathrm{RH} \mathrm{u}$ Domovinskom ratu, a u sukobu je ubijen i jedan srpski napadač. ${ }^{35}$

Dan poslije vodstvo pobunjenih Srba donijelo je Odluku o prisajedinjenju SAO Krajine Republici Srbiji i izdalo zapovijed za mobilizaciju Teritorijalne obrane SAO Krajine, čime je praktično razotkrilo svoj glavni cilj. Naravno, zbog međunarodnih okolnosti i dnevnopolitičkih potreba Srbija tada nije mogla prihvatiti takvu odluku, niti je Teritorijalna obrana bila mobilizirana. ${ }^{36}$

Jugoslavenska narodna armija intervenirala je već u sukobima u Pakracu i na Plitvicama. ${ }^{37}$ Vodstvo pobunjenih Srba u Hrvatskoj očekivalo je da će se JNA prilikom intervencije oružano sukobiti s hrvatskom policijom, ${ }^{38}$ što je mogao biti povod za uvođenje izvanrednoga stanja u državi, no to se nije dogodilo. Hrvatsko vodstvo vodilo je politiku izbjegavanja sukoba s JNA. Nakon događaja u Pakracu propao je i plan vodstva Srbije i JNA da se na sjednici Predsjedništva SFRJ od 12. do 15. ožujka 1991. ishodi uvođenje izvanrednoga stanja u državi. To su onemogućili predstavnici Hrvatske, Makedonije i BiH u dramatičnom glasanju 12. ožujka, u kojem je presudan bio glas predstavnika BiH, Srbina Bogića Bogićevića (predstavnik Slovenije, Janez Drnovšek,

\footnotetext{
${ }^{34}$ „Poziv na sjednicu Glavnog odbora SDS-a”, sazvanu za subotu 2. veljače 1991., koji je 29. siječnja 1991. u Šibeniku potpisao predsjednik SDS-a akademik Jovan Rašković, u: RUPIĆ, Dokumenti: Dokumenti institucija pobunjenih Srba, 130.

${ }^{35}$ BRIGOVIĆ, MARTINIĆ JERČIĆ, RADOŠ, „Prvi oružani napadi na hrvatske redarstvene snage 1991.", 4-18.

${ }^{36}$ MARIJAN, Hrvatska 1989. - 1992., 301-302, 311; MARIJAN, Obrana i pad Vukovara, 54.

${ }^{37}$ MARIJAN, Domovinski rat, 72-73.

${ }^{38}$ HR-HMDCDR-8, 9. K JNA, kut. 22, „Dnevnik rada Organa bezbednosti 9. korpusa JNA”, nadnevak 31. 3. i 3. 4. 1991.
} 
toga dana nije nazočio sjednici). ${ }^{39}$ General Veljko Kadijević odmah nakon sjednice, uz Jovićevu suglasnost, otišao je u Moskvu na razgovor s Dmitrijem Jazovom, ministrom obrane Sovjetskoga Saveza, i vratio se iste večeri. Prema Jovićevu zapisu, nakon povratka iz Moskve Kadijević je rekao da treba ići na vojni udar te smjenjivanje Vlade i Predsjedništva. ${ }^{40}$ Zbog toga što prijedlozi koje je podnio „Štab Vrhovne komande o preduzimanju mera pripravnosti u oružanim snagama SFRJ i o preduzimanju mera za dovođenje narušenog sistema odbrane zemlje u Ustavom utvrđene okvire" nisu prihvaćeni, na kraju sjednice general Kadijević poručio je, zapravo zaprijetio, da „Štab Vrhovne komande uzima sebi pravo i obavezu da odmah, nakon ove odluke, procijeni situaciju i povuče konsekvence koje iz njih proizlaze". ${ }^{41}$

Dan nakon sjednice Predsjedništva SFRJ, 16. ožujka 1991., Slobodan Milošević rekao je na „zatvorenom sastanku” predstavnicima srbijanskih mjesnih vlasti da se „ne dovodi u pitanje odcjepljenje Slovenije, koja ima tu sreću da se etničke granice podudaraju s državnim granicama”, te istaknuo: „Ja sam rekao doslovce da nam ni na pamet ne pada da osporavamo pravo hrvatskog naroda da izađe iz Jugoslavije... Ali da nikome ne sme da padne na pamet da odvoji iz Jugoslavije deo srpskog naroda koji živi u Hrvatskoj... Mi moramo obezbediti jedinstvo u Srbiji ako želimo da kao Republika koja je najveća, koja je najbrojnija, diktiramo daljni tok događaja. To su pitanja granica, prema tome suštinska, državna pitanja. A granice, kao što znate, uvek diktiraju jaki, nikada ne diktiraju slabi... Mi jednostavno smatramo da je legitimno pravo i interes srpskog naroda da živi u jednoj državi. I to je početak i kraj. [...] A ako treba da se tučemo, bogami ćemo da se tučemo. A nadam se da neće biti toliko ludi da se s nama tuku. Jer ako ne umemo dobro da radimo i privređujemo, bar ćemo znati dobro da se tučemo." ${ }^{2}$

Prema Jovićevu dnevniku, 17. ožujka 1991. general Kadijević predložio je njemu i Miloševiću dvije varijante: „1. Rok s ultimatumom; 2 . Izvršenje bez ultimatuma. Ako to ne bi uspjelo onda se blokira vlast, uspostavlja se vojna uprava i upotrebljava sila." Pritom je iznio varijante djelovanja JNA (oduzimanje oružja Hrvatima, stavljanje Teritorijalne obrane Slovenije u ustavne okvire, podizanje borbene spremnosti, slanje regruta, mobilizacija), ${ }^{43}$

${ }^{39}$ HR-HDA-UPRH, Stenografske beleške sa sednice Predsedništva SFRJ u funkciji Vrhovne komande, održane 15. 3. 1991. Stenogram sjednice „Vrhovne komande OS SFRJ” održane 12., 14. i 15. ožujka 1991. u skraćenoj je verziji objavljen u tiskovini JNA Narodna armija (5. 10. 1991., 10-13). Preuzet je iz jednosatne emisije koju je „Služba za informisanje SSNO” pod naslovom „Ko izdaje zemlju” emitirala na TV Beograd u „udarnom večernjem terminu” 2. listopada 1991. godine. KADIJEVIĆ, Moje viđenje raspada, 113; JOVIĆ, Poslednji dani SFRJ, 286-295; MARIJAN, Domovinski rat, 72.

40 JOVIĆ, Poslednji dani SFRJ, 295-296.

${ }^{41}$ JOVIĆ, Poslednji dani SFRJ, 304.

${ }^{42}$ „Ako ne umemo dobro da radimo, bar ćemo znati dobro da se tučemo - Izvodi iz stenografskih beležaka sa sastanka predsednika Republike Slobodana Miloševića i potpredsjednika Narodne skupštine Republike Srbije sa predsednicima skupština opština Srbije, održanog 16. marta 1991.", Vreme (Beograd), 15. 4. 1991., 62-66.

${ }^{43}$ JOVIĆ, Poslednji dani SFRJ, 306-310. 
što potvrđuje da su dio vodstva JNA i srbijansko vodstvo tada bili spremni na radikalne mjere i da su u svojem djelovanju bili spremni prijeći granice ustavnoga djelovanja. U skladu s tim, Jović će ubrzo u svojem dnevniku, 5. travnja 1991., zaključiti: „U svakom slučaju, prešli smo 'Rubikon'. [...] Ni od koga više ne tražimo nikakve odluke, dejstvujemo prema potrebi na zaštiti srpskog naroda, obaveštavamo Predsedništvo o događajima, pa kome se ne dopada neka ide kući. I glupo je da sede u rukovodstvu države s kojom su zaratili." ${ }^{44}$ Događaji koji su uslijedili zorno su potvrdili da su srbijansko vodstvo i JNA zaista „prešli Rubikon”.

Ubojstva 13 hrvatskih policajaca u Borovu Selu i Polači 2. svibnja 1991.

Stanje u Hrvatskoj dramatično se pogoršalo kada su 2. svibnja 1991. srpski teroristi iz zasjede ubili 13 hrvatskih policajaca: 12 u Borovu Selu (Slavonija) te jednoga u Polači kod Zadra (Dalmacija).

\section{Ubojstvo 12 hrvatskih policajaca u Borovu Selu 2. svibnja 1991.}

Prema popisu stanovništva iz 1991., općina Vukovar imala je 84189 stanovnika: 36910 Hrvata (43,8 \%), 31445 Srba (37,4 \%), 1375 Mađara (1,6 \%), $6124(7,3 \%)$ onih koji su se izjasnili kao Jugoslaveni i 8335 (9,9 \%) ostalih ili neopredijeljenih. Grad Vukovar imao je 1991. ukupno 44639 stanovnika: 21 065 Hrvata (47,2 \%), 14425 Srba (32,3 \%), 919 Rusina (2,1 \%), 694 Mađara $(1,5 \%), 147$ Slovaka $(0,3 \%), 94$ Nijemca $(0,2 \%), 4355$ onih koji su se izjasnili kao Jugoslaveni $(9,8 \%)$ te 2940 (6,6 \%) ostalih ili neopredijeljenih. ${ }^{45}$

Politička situacija na vukovarskom području postala je složenija nakon što je na osnivačkoj skupštini SDS-a na vukovarskom izletištu Adica 10. lipnja 1990. govorio njegov čelnik Jovan Rašković. Sigurnosna situacija znatno se pogoršala nakon što su u veljači i ožujku 1991. u istočnoj Slavoniji i vukovarskoj općini održani mitinzi, na kojima su okupljeni Srbi otvoreno prijetili Hrvatima i hrvatskoj vlasti, a posebice nakon oružanoga sukoba između hrvatske policije i srpskih terorista na Plitvicama 31. ožujka 1991. godine. Srpski ekstremisti tada su postavili barikade u Borovu Selu, a potom i u ostalim selima vukovar-

\footnotetext{
${ }^{44} \mathrm{Uz}$ to je Jović, opisujući sadržaj razgovora njega i S. Miloševića s generalima JNA V. Kadijevićem i B. Adžićem, 5. travnja 1991. u svoj dnevnik zapisao da je, među ostalim, zaključeno da bi, s obzirom na to da tzv. srpski blok u Predsjedništvu SFRJ nije imao većinu, stav da vojska ne smije koristiti oružje bio katastrofalan za srpski narod u Hrvatskoj, da JNA neće dopustiti da hrvatska policija zauzme Knin i druge „srpske” gradove koji su sada pod srpskom vlašću, a da će, ako ih Hrvati napadnu, vojska „stupiti u oružano dejstvo” i obavijestiti Jovića, koji će potom sazvati Predsjedništvo i samo ga obavijestiti o tome, bez traženja suglasnosti. Jović je generalima rekao da bi svako drugačije postupanje bilo izdaja, a izdaja znači pad srpskoga rukovodstva i JNA, s čime su se generali složili (JOVIĆ, Poslednji dani SFRJ, 317).

${ }^{45}$ CRKVENČIĆ-BOJIĆ, Popis stanovništva 1991., 206-209.
} 
ske općine naseljenim pretežito srpskim stanovništvom - Pačetinu, Boboti, Bršadinu, Negoslavcima, Trpinji. Na barikadi u Bršadinu pucali su 2. travnja na civilni automobil, pri čemu je teško ranjena suvozačica. ${ }^{46}$

U travnju 1991., u pratnji ekstremista i dobrovoljaca iz raznih krajeva Srbije, Slavoniju i Baranju obilazili su srbijanski političari: čelnik Srpske radikalne stranke te zastupnik u Skupštini Srbije četnički vojvoda Vojislav Šešelj, član srpskoga parlamenta Milan Paroški i ministar u srpskoj vladi Stanko Cvijan. Govorima mržnje na raznim mitinzima, primjerice u Borovu Selu 14. travnja 1991., javno su pozivali Srbe na pobunu protiv hrvatske vlasti i na obračun s Hrvatima na tom području radi pripajanja Slavonije i Baranje Srbiji i stvaranju Velike Srbije. Takva huškačka i agresivna retorika srpskih političara bila je uvod u krvavi rat u istočnoj Slavoniji i drugim dijelovima Hrvatske. Šaljući ministra unutarnjih poslova Josipa Boljkovca i njegova zamjenika Slavka Degoriciju u Vukovar 15. travnja, hrvatska vlast pokušala je novim razgovorima s predstavnicima političkih stranaka iz sela s većinskim srpskim stanovništvom izbjeći oružane sukobe koji su prijetili na vukovarskom području i prijepore riješiti mirno. ${ }^{47}$

Potom je na mitingu u baranjskom selu Jagodnjak 21. travnja 1991. Milan Paroški, među ostalim, rekao: „Ovo je srpska teritorija i njima [Hrvatima, op. a.] mora biti jasno da su oni dođoši. Prema tome, tko god vam dođe i kaže da je ovo njegova zemlja, taj je uzurpator, taj je došao da ubija i tog imate prava da ubijete kao kera pored tarabe!" Ubrzo nakon toga srpski teroristi (četnički dobrovoljci iz Srpske radikalne stranke Vojislava Šešelja i Srpske narodne obnove Mirka Jovića te lokalni Srbi kojima je zapovijedao Vukašin Šoškoćanin) u Borovu Selu kod Vukovara iz zasjede su ubili 12 pripadnika Posebne jedinice policije Policijske uprave (PU) Vinkovci. Ubijeni su: Ivica Vučić iz Vinkovaca, Luka Crnković i Zoran Grašić iz Otoka, Marinko Petrušić iz Tovarnika, Antun Grbavac iz Nijemaca, Mladen Šarić iz Novih Jankovaca, Stipan Bošnjak i Zdenko Perica iz Nuštra, Željko Hrala i Janko Čović iz Ivankova, Josip Culej iz Jarmine i Mladen Čatić iz Županje. Ranjena su 23 policajca, a jedan poginuo i više ranjenih bilo je na srpskoj strani. ${ }^{48}$

Prema priznanju V. Šešelja, četnički dobrovoljci iz Srbije došli su u Borovo Selo najkasnije početkom travnja 1991., ${ }^{49}$ a priprema krvoprolića nije prošla bez znanja srbijanske Službe državne bezbednosti. ${ }^{50}$ Nazočnost četnika na

${ }^{46}$ NAZOR, Grad je bio meta, 39-40.

${ }^{47}$ NAZOR, Grad je bio meta, 40.

${ }^{48}$ Hrvatska policija u Domovinskom ratu, 110.

49 Velika Srbija (Beograd), maj 1994., 37. Među izvorima koji potvrđuju sudjelovanje Vojislava Šešelja u prikupljanju i slanju naoružanih dobrovoljaca u Hrvatsku radi sukoba s hrvatskim snagama i osvajanja teritorija jest i članak „Srpska mi truba zatrubi iz toga sela Borova”, objavljen u Velikoj Srbiji (br. 11, decembar 1991., 25-29). U njemu se, u svjedočenju srpskih dobrovoljaca koji su 2. svibnja 1991. sudjelovali u oružanom sukobu u kojem je iz zasjede ubijeno 12 hrvatskih policajaca, spominju „četnici vojvode Šešelja”.

${ }^{50} \mathrm{O}$ ubojstvu hrvatskih policajaca u Borovu Selu i događajima na vukovarskom području koji su tome prethodili opširnije vidi u: MARIJAN, Obrana i pad Vukovara, 41-61. 
tom području uoči ubojstva 12 hrvatskih policajaca u Borovu Selu potvrđuju i izvori JNA. ${ }^{51}$

O događajima u Borovu Selu 2. svibnja 1991. govori „Iskustvo o angažovanju jedinice JNA na razdvajanju sukobljenih strana MUP Hrvatske i mještana u Borovu selu" (br. 2445-1, od 7. 6. 1991.), koje je Komandi 17. korpusa JNA uputio načelnik Štaba 12. proleterske mehanizovane brigade JNA potpukovnik Dušan Lončar. Ovdje su izdvojeni dijelovi dokumenta zanimljivi za saznanja o vremenu i tijeku sukoba, odnosno izvlačenju pripadnika MUP-a iz sela:

„- Upad MUP-a u Borovo Selo izvršen je u 12,05 časova. [...]

- 12,35 ŠTO [Štab teritorijalne odbrane] opštine Vukovar obaveštava komandanta garnizona Vukovar da se u Borovu Selu puca. [...]

- 12,43 prenesen signal za dežurnog kasarne da uzbuni jedinice, [...]

- 13,10 potpukovnik Lončar se javio dežurnom oficiru i stupio u kontakt sa komandantom 17. Korpusa kojom prilikom je dobio naređenje sledeće sadržine: 'Formirati jedinicu sastava: 1 . vod čVP [četa Vojne policije] (četiri vozila) i vod ič [interventne čete] (3 vozila), jedinicom rukovodi lično potpukovnik Lončar...' $[\ldots]$

- 13,40 Formirana kolona napušta kasarnu i odlazi u Borovo. [...] Odlučeno je da je prilaz Borovu Selu sa pravca Dalja povoljniji jer je manje naseljen i manja je mogućnost ometanja kolone. [...]

- 14,05 časova 1000 m po izlasku iz s. Dalj, a na ivici s. Borovo Selo primećena su 2 borbena vozila MUP-a, 1 autobus i više osobnih vozila, a desno i levo od ceste pripadnici MUP-a u streljačkom stroju u raznim položajima (ležeći, klečeći i stojeći) koji su otvarali vatru u pravcu s. Borovo Selo. [...] Na ulasku u s. Borovo Selo, a na udaljenosti od pripadnika MUP-a na oko 200-300 metara postavljena je barikada koju su branili stanovnici sela. [...] Jedinica je ušla u selo i nakon 200300 metara se zaustavila s obzirom da u tom delu sela nije vođena borba. Izašao sam iz transportera i od meštana sela saznao da se borba težišno vodi u centru sela i sa pravca Borova. [...] Građane sela sam upozorio da ne otvaraju vatru, da ćemo sprečiti dalji prodor MUP-a. (Jedan) vod je poseo položaj rasporedivši se na frontu (oko 150 metara) u gotovosti za otvaranje vatre [između barikade na ulasku u selo i pripadnika MUP-a, op. a].

\footnotetext{
${ }^{51}$ Primjerice, u „informativnom razgovoru” s vodnikom JNA od 14. svibnja 1991. navedeno je: „Za vreme prvomajskog praznika putovao sam kod roditelja u Vukovar. U Vukovaru roditelji imaju stan, a nadomak Borova Sela imaju vikendicu. [...] Tih dana pred Prvi maj nismo mogli da odemo do vikendice. To vikend naselje nalazi se pored Borova Sela i taj se deo zove Sovulje. Prvi put kada smo pokušali da odemo do vikendice, nedaleko od vikend naselja zaustavila su nas dva naoružana čoveka sa svim obeležjima četnika. Imali su duge brade, šubare na glavi sa kokardama, a od naoružanja su imali TOMPSONE 11,9 mm, bombe i kame. Ja nisam mogao, da verujem kad sam ih video; mada sam pre toga čuo da u tom kraju ima četnika. Stvarno su delovali zastrašujuće. Roditeljima i meni su rekli da trenutno ne možemo do vikendica. Po mom mišljenju nisu nas pustili iz razloga što je jedna grupa tih četnika i dobrovoljaca iz Srbije bila smeštena pored Dunava, nadomak vikend naselja. O tome su i stanovnici pričali: da su smešteni na tom mestu u šatorima." Vidi u: RUPIĆ, Dokumenti: Oružana pobuna Srba u Hrvatskoj, 131136.
} 
Sa preostalim delom snaga (4 BOV čVP) [borbena oklopna vozila čete Vojne policije] produžio sam pokret kroz selo. [...] Kada smo se približili centru sela, čula se paljba jačeg intenziteta, a primetio sam i naoružane civile u sporednim ulicama i dvorištima. [...] U samom centru sela, posebno na platou ispred MZ [Mjesne zajednice] i gostionice, a posebno na prvoj kući sa leve strane u pravcu nailaska bili su vidljivi tragovi borbe: razbijena stakla, oštećene fasade, dva civila u ležećem položaju na platou ispred MZ, kao i veći broj uniformisanih lica u maskirnim odelima koji su ležali ispred kuće do MZ i u obližnjem kanalu, a na cesti razbijena 3 osobna vozila, 1 landrover, kao i 1 autobus. Vatra je i dalje obostrano otvarana. [...] Produžio sam pokret u pravcu Borova u cilju sagledavanja obima sukoba s obzirom da u samom centru nisam mogao razlučiti gde su sukobljene snage, jer su se iste nalazile u kućama i po dvorištima. Kad smo izbili na ivicu Borova Sela (ka Borovu) intenzitet vatre je bio znatno jači. Na pravcu Borovo Selo - Borovo uočio sam borbeni raspored pripadnika MUP-a kao i zaustavljenu kolonu raznih oštećenih vozila. Ponovo sam upozorio obe strane da prekinu vatru, jer ćemo u protivnom po istim dejstvovati. Nakon kratkog sagledavanja situacije odlučio sam da sukobljene strane na ovom pravcu razdvojim sa $2 \mathrm{~b} / \mathrm{v}$, a sa preostala $2 \mathrm{~b} / \mathrm{v}$ da se vratim u centar sela, jer sam procenio da se tamo rukovodi akcijom.

- 15,00 Uspostavio sam vezu sa dežurnim brigade i izvestio da izvršavam zadatak po planu i da je sukob širih razmera... [...] Prilikom povratka primećivao sam grupe naoružanih civila koji su se sada već slobodnije pokazivali i rukama upućivali ka zgradi MZ gde se nalaze pripadnici MUP-a, očito smatrajući da smo im došli u pomoć i da ćemo se boriti protiv MUP-a. Intenzitet vatre je bio bitno smanjen sem sporadičnih dejstava. [...] S obzirom da nije bilo moguće uspostaviti kontakt sa pripadnicima MUP-a u centru sela odlučio sam da se vratim na početak sela sa pravca Borova i da tamo stupim u kontakt sa pripadnicima MUP-a i zahtevam prekid vatre. Po odlasku iz centra sela vatra je obostrano pojačana. [...] Lice sa kojim sam stupio u kontakt predstavio se kao inspektor Čopčić i rekao je da on ne komanduje čitavom akcijom i da nema ovlaštenja da prekine borbu, te da je inspektor Bošnjak koji rukovodi akcijom poginuo. [...] ... dobio je odobrenje od Džaje, šefa Policijske uprave Vinkovci da se prekine dejstvo. [...] Zahtevao sam da inspektor Čopčić uđe u moje b/v kako bi u centru sela obezbedio stupanje u kontakt sa pripadnicima MUP-a, što je on i učinio. [...] Sa b/v prišao sam kući koliko god je bilo moguće bliže, a da ne budem izložen dejstvu pripadnika MUP-a i meštana, i pored toga sam morao proći oko 20 metara brisanog prostora. Izašli smo iz vozila u pratnji dva vojnika i uputili se ka kapiji. U tom trenutku meštani su ponovo pucali upozoravajući nas da se ne približavamo kući (pogrdnim rečima i psovkama). Produžili smo pokret uočavajući veći broj mrtvih pripadnika MUP-a, kao i ranjenika koji su zapomagali. Preko pojedinih poginulih morali smo prekoračiti da bi mogli ući u dvorište kuće. [...] Razmak između meštana i nas iznosio je oko 50 metara. Kada smo ušli u dvorište primetili smo veći broj pripadnika MUPa raspoređenih po objektima u gotovosti za otvaranje vatre, a u samoj kući oko 20 pripadnika MUP-a (najveći broj ranjen, a 1 poginuo). [...] 
Inspektora Čopčića ostavio sam u kući, izašao van dvorišta i krenuo ka meštanima sela, koji su se i dalje veoma neprijateljski odnosili prema meni, uz upozoravajuće pucnjeve u vazduh. Kada sam im se približio, tražio sam da stupim u vezu sa nekim od rukovodilaca akcije odbrane sela. Jedan od meštana, koji se predstavio kao Vule, rekao je kako je on jedan od rukovodećih ljudi i da želi da sve MUP-ovce pobije jer su kao razbojnici upali u selo pucajući na sve živo, a da u ambulanti i pošti drže žene i decu kao taoce, te da sa takvim ljudima nema pregovora. Rekao sam mu da imam zadatak za sprečim dalji sukob, da pripadnici MUP-a napuste selo, a da ću prethodno osloboditi taoce. Ovo nije prihvaćeno od strane pregovarača. Nakon ovog razgovora otišao sam u poštu i utvrdio da se u istoj nalazi nekoliko dece i žena, ali da nema pripadnika MUP-a, ali da jednostavno ne mogu da izađu zbog vatre koja se stvarala.

Ponovo sam otišao u sporednu ulicu, van dejstva jedne i druge strane, prišao grupi naoružanih građana i tražio ponovo nekoga ko rukovodi akcijom odbrane sela. Javio se jedan seljanin naoružan puškom i TOMSONOM i predstavio se kao Marko (Marko Lončarević). Rekao sam mu da insistiram na prekidu vatre, kao i da su dalja dejstva pogubna po selo, da MUP raspolaže sa RB i bombama sa kojima još nije dejstvovao i da će selo, ukoliko se nastavi borba, imati velike gubitke. Nakon toga se Marko složio da se dejstva prekinu, ali da on to ne može odlučiti sam već se mora konsultovati sa Vuletom (Vukašin Šoškoćanin). Posle razgovora sam zajedno sa Markom, b/v [borbenim vozilom] otišao do Vukašina. Razgovorom sa ovom dvojicom odlučeno je da se prekine vatra, oslobode taoci, pruži pomoć ranjenicima i izvezu poginuli. Za sve ovo vreme nije bilo dozvoljeno pružanje pomoći ranjenicima niti ulazak sanitetskih vozila u selo. [...] Iz sela je ukupno izvezeno oko 60 pripadnika MUP-a, od čega $12 \mathrm{mrtvih}$, nakon čega su se povukle snage MUP-a koje su napadale selo sa pravca Dalja i Borova. [...]

Slabosti: Nedovoljan i neorganizovan obaveštajno-izviđački rad, u celini, s obzirom da je već u 10,00 časova bilo izvesnih saznanja o mogućem napadu na s. Borovo Selo, a u vezi događaja prethodne noći, a u vezi zarobljavanja 2 pripadnika MUP-a u Borovu Selu. [...]"52

\section{Ubojstvo hrvatskoga policajca Franka Lisice u Polači 2. svibnja 1991.}

Istoga dana kada su ubijeni hrvatski policajci u Borovu Selu, 2. svibnja 1991., na drugom kraju Hrvatske, u Polači u zaleđu Zadra, srpski su teroristi iz zasjede ubili još jednoga policajca: Franka Lisicu, pripadnika zadarske specijalne jedinice policije „Poskoci”.

Na području sjeverne Dalmacije prema popisu stanovništva iz 1991. Srbi su imali apsolutnu većinu u općinama Knin (88,2 \%), Obrovac $(65,5 \%)$ i Benkovac $(56,9 \%)$, s tim da su u potonje dvije Hrvati bili zastupljeni u znatnijem postotku - Obrovac 32,5\% i Benkovac 40,6 \%. Hrvati su apsolutnu većinu

\footnotetext{
52 „Iskustvo o angažovanju jedinice JNA na razdvajanju sukobljenih strana MUP Hrvatske i mještana u Borovu selu”, br. 2445-1, od 7. 6. 1991. (dokument u posjedu autora).
} 
imali u općinama Biograd na Moru (92,1 \%), Drniš (77,5 \%), Šibenik (84 \%) i Zadar (82,9 \%), a Srbi su bili znatnije zastupljeni samo u općini Drniš sa 20,6 $\%$ stanovnika. ${ }^{53}$ Vidljivo je da je znatan dio toga teritorija bio heterogen, kao i na području Vukovara, te kao takav pogodan za širenje međunacionalnoga sukoba. Osobito je nepovoljna situacija bila za hrvatsko stanovništvo u mjestima koja su bila okružena selima naseljenim srpskim stanovništvom i/ili nalazila su se na području koje su pobunjeni Srbi smatrali teritorijem SAO Krajine. ${ }^{54}$

Već za vrijeme sukoba na Plitvicama, 31. ožujka 1991., na području Benkovca i Obrovca dignut je dio rezervista koji su išli u pomoć pobunjenicima na Plitvičkim jezerima. U večernjim satima oni su se vratili iz Like te organizirali „obranu u Ben[kovcu] i Obr[ovcu]”. Nakon toga na području tih općina organizirale su se straže i nadzirale prometnice i raskrižja. ${ }^{55} \mathrm{Na}$ području općine Benkovac u selima naseljenim srpskim stanovništvom straže su držali mještani i „milicioneri”, a u selima naseljenim hrvatskim stanovništvom straže su držali samo mještani. ${ }^{56}$

Nakon toga je uslijedilo sve učestalije podmetanje ili bacanje eksplozivnih naprava, većinom na imovinu Hrvata i Albanaca, no i Srba koji se nisu slagali $s$ radikalnom politikom tamošnjega srpskog vodstva, urušavanje prometnica $i$ zaprečivanje komunikacija, pucanje na civile na prometnicama, maltretiranje novinara... ${ }^{57}$ To je primoralo PU Zadar na osnivanje policijskih ispostava na tom području u mjestima naseljenim hrvatskim stanovništvom. Ispostave su osnovane u mjestima Stankovci (2. travnja), Kruševo (20. travnja), Jasenice (22. travnja), Pridraga (24. travnja) i Polača (26. travnja) te u srpnju 1991. u Lišanama Ostrovičkim. ${ }^{58}$

Polača se nalazi na zapadnom dijelu općine Benkovac koji graniči s teritorijem općine Biograd na Moru. Kroz nju prolazi prometnica iz Benkovca prema Biogradu na Moru. S južne i istočne strane Polače nalazila su se mjesta naseljena srpskim stanovništvom, što je dodatno otežavalo održavanje javnoga reda i mira na tom području.

\footnotetext{
${ }^{53}$ CRKVENČIĆ-BOJIĆ, Popis stanovništva 1991., 18, 20, 22, 24.

${ }^{54}$ HR-HMDCDR-8, 9. K JNA, kut. 22, „Dnevnik Organa bezbednosti 9. korpusa JNA”, nadnevak 25. 4. 1991.

${ }^{55}$ HR-HMDCDR-8, 9. K JNA, kut. 22, „Dnevnik Organa bezbednosti 9. korpusa JNA”, nadnevak 31. 3. 1991.

${ }^{56}$ HR-HMDCDR-8, 9. K JNA, kut. 22, „Dnevnik Organa bezbednosti 9. korpusa JNA”, nadnevak 1. 4. 1991.

${ }^{57}$ HR-HMDCDR-8, 9. K JNA, kut. 22, „Dnevnik Organa bezbednosti 9. korpusa JNA”, vidi nadnevke 4., 7., 8., 13., 14., 16., 17., 18., 20., 24. i 25. travnja 1991.

${ }^{58}$ Podatke o osnivanju policijskih ispostava u PU Zadar 1991. godine HMDCDR je dobio od PU zadarske 9. studenog 2018. godine. Vidi još: Suzana BANDIĆ, „Spomen ploča kao dokaz hrvatske opstojnosti”, Zadarski list (Zadar), on-line izdanje, 21. 4. 2010., pristup ostvaren 14. 12. 2018., https://www.zadarskilist.hr/clanci/21042010/spomen-ploca-kao-dokaz-hrvatskeopstojnosti; „Obilježavanje obljetnice policijske ispostave Pridraga”; „Otkrivena spomen ploča bivše Policijske ispostave Stankovci". O okolnostima osnivanja policijskih stanica u RH vidi u: MARIJAN, Hrvatska 1989. - 1992., 495.
} 
Osnivanje Policijske ispostave MUP-a RH u Polači, kao i u drugim spomenutim mjestima sjeverne Dalmacije, nije spriječilo srpske teroriste, predvođene Milanom Martićem, da nastave s teroriziranjem stanovništva toga područja. Tako su 26. travnja 1991. srpski teroristi na putu od Kakme prema Polači na području Donje Jagodnje otvorili rafalnu paljbu na kamion Poljoprivredne zadruge Polača koji se iz Biograda na Moru kretao prema Polači, pri čemu su ranjeni vozač i suvozač. ${ }^{59}$ Istoga je dana Općinski odbor SDS-a Benkovac iznio priopćenje u kojem su zbog „upada redarstvenika nama susedne republike Hrvatske u opštinu Benkovac, tačnije u s[elo] Polača”, tražili od „agresora, odnosno hrvatskih bojovnika da se povuku sa naše teritorije jer za eventualne posledice sami će snositi odgovornost". ${ }^{60}$ To se očito odnosilo na uspostavljanje ispostave MUP-a u Polači.

Zbog sve složenije sigurnosno-političke situacije postrojbe JNA pojačale su svoje ophodnje te stupile u kontakt s hrvatskim policajcima u Polači, gdje im je rečeno da je ondje uspostavljena policijska postaja. Tu je informaciju kapetanu I. klase JNA Branislavu Ristiću kasno navečer potvrdilo vodstvo zadarske policije. Zanimljivo je da je zbog tog razgovora kapetanu Ristiću poslije prigovorio načelnik „organa bezbednosti” Vojnopomorske oblasti Jugoslavenske ratne mornarice, kapetan bojnog broda Ljubiša Beara - „kako je mogao Ristić da ćakula s neprijateljem 30 minuta posle ponoći” - iz čega se jasno vidi na čiju se stranu svrstao zapovjedni kadar JNA. ${ }^{61}$ Ubrzo potom, već 28. travnja, srpski su teroristi iz smjera sela Stabanj i Kakma u prijepodnevnim satima pucali na ophodnju hrvatske policije u Polači. ${ }^{62}$ Svi ti napadi bili su uvod u krvavi događaj 2. svibnja 1991. godine.

Prema informacijama koje je dobila JNA, u sukobu pripadnika SUP-a Knin i MUP-a RH jedan je hrvatski policajac prijepodne 2. svibnja ranjen u Polači, no preminuo je istoga dana u zadarskoj bolnici. ${ }^{63}$

Službene podatke hrvatske strane o ubojstvu hrvatskoga policajca Franka Lisice, rođenog 24. rujna 1968., s mjestom boravka u Bibinju, donosi spis Policijske uprave zadarske, koji je Služba kriminalističke policije sastavila pod naslovom FRANKO LISICA, KD „UBOJSTVO”, 02.05.1991.g, brdo Štrkovača kod Polače. U „Krivičnoj prijavi” od 3. svibnja 1991., kojom započinje spomenuti spis, a koju je Policijska uprava Zadar - Policijska stanica Biograd na Moru (zapovjednik Marin Orlić), „na osnovi člana 151. stav 6. Zakona o krivičnom postupku” podnijela „Okružnom javnom tuži-

${ }^{59}$ HR-HMDCDR-8, 9. K JNA, kut. 22, „Dnevnik Organa bezbednosti 9. korpusa JNA”, nadnevak 26. 4. 1991.

${ }^{60}$ HR-HMDCDR-8, 9. K JNA, kut. 22, „Dnevnik Organa bezbednosti 9. korpusa JNA”, nadnevak 26. 4. 1991.

${ }^{61}$ HR-HMDCDR-8, 9. K JNA, kut. 22, „Dnevnik Organa bezbednosti 9. korpusa JNA”, nadnevak 28. 4. 1991.

${ }^{62}$ HR-HMDCDR-8, 9. K JNA, kut. 22, „Dnevnik Organa bezbednosti 9. korpusa JNA”, nadnevak 28. 4. 1991.

${ }^{63}$ HR-HMDCDR-8, 9. K JNA, kut. 22, „Dnevnik Organa bezbednosti 9. korpusa JNA”, nadnevak 2. 5. 1991. 
ocu Zadar” protiv „nepoznatog učinioca krivičnog djela iz čl. 35. KZ SFRJ”, stajalo je:

„Dana 02.05.1991. godine oko 10.30 sati na brdu Štrkovača, kod mjesta Polača, SO Benkovac, više nepoznatih osoba, od kojih je većina bila u uniformi, iz automatskog oružja pucali su na patrolu Policijske uprave Zadar, koja je bila u redovnom obilasku terena i tom prilikom smrtno pogodili policajca Lisica Franka.

Policijska patrola u sastavu Ikić Ante, zapovjednik Posebne jedinice Polača, Konjarević Stjepan, pomoćnik zapovjednika i Lisica Franko, policajac, oko 9.30 sati krenuli su preko brda Gradina, radi identifikacije osoba koje su primjetili na Štrkovači. Nakon rasporeda na terenu, kojeg je postavio zapovjednik Ikić, sva trojica počeli su se šuljajući primicati vrhu Štrkovače. $\mathrm{Na}$ ledinu neposredno ispod brda prvi je stigao Lisica Franko i u trenutku dok je pretrčavao čist prostor s vrha brda ispaljeno je više metaka od kojih ga je jedan smrtno pogodio. Nakon toga Ikić je otvorio vatru iz 'Heklera' u pravcu vrha brda, a Konjarević je, zajedno sa policajcima koji su došli kao pojačanje, odnio tijelo policajca Franka u mjesto Polaču, odakle je kolima prve pomoći iz Zemunika Donjeg prebačen u Medicinski centar Zadar. Uslijed puščane paljbe nepoznate osobe sa vrha Štrkovače pobjegle su u pravcu Jagodnje Gornje, zaseok 'Zečevići'.

$\mathrm{Na}$ mjestu odakle su pucali na policijsku patrolu pronađena je: snajper puška broj 44568, 6 komada trenutnih mina M-60, 8 komada tromblonskih mina, 2 komada ručnih improviziranih bombi sa sporogorućim štapinom, 2 rapa sa po 4 okvira napunjena po 30 metaka, 1 vojni ranac sa više komada rasute municije, pretežno cal. 7,9 i 7,62 mm, 1 manji ranac sa 150 metaka cal. $7,62 \mathrm{~mm}, 1$ rap za snajpersku pušku sa 4 okvira po 10 metaka cal. 7,9 mm, 3 okvira za automat 'Tomson', od kojih su 2 puna municije i 1 crni izvijač. $\mathrm{Na}$ licu mjesta nije vršen uviđaj iz sigurnosnih razloga.

Sa zapovjednikom Posebne jedinice u Polači i njegovim pomoćnikom obavljen je informativni razgovor, o čemu su sastavljene službene zabilješke koje vam u prilogu dostavljamo. U prilogu vam također dostavljamo fotoelaborat, izvještaj o pronađenom oružju i municiji, zahtjev za balističko vještačenje i zahtjev za analizu krvi i urina pokojnog policajca Lisica Franka." ${ }^{4}$

U službenoj zabilješci razgovora sa sudionicima događaja Antom Ikićem i Stjepanom Konjarevićem, koju je 2. svibnja 1991. u Policijskoj upravi Zadar Odjel za operativne poslove Javne sigurnosti (JS) sastavio i potpisao inspektor I. klase Adem Mehmedović, uglavnom se nalaze isti podaci kao u spomenutoj Krivičnoj prijavi. ${ }^{65}$ U službenom su spisu i rezultati liječničkoga pregleda,

\footnotetext{
${ }^{64}$ Služba kriminalističke policije - FRANKO LISICA, KD „UBOJSTVO”, 02.05.1991.g, brdo Štrkovača kod Polače, broj: KU-80/91, od 3. 5. 1991. (dokument u posjedu autora).

65 Inspektor Mehmedović sastavio je i potpisao i Izvještaj o pronađenom oružju i streljivu u PS Polača 2. svibnja 1991., u kojem je navedeno isto što i u tekstu, uz manje razlike: spominje se marka snajpera - „Zrak” (broj 8718136, tip ON-M-76B) te da je u manjem rancu nađeno i 10 metaka kalibra 7,62 za pištolj i da su sva tri okvira za automat „Tomson” bila „vezana izolir
} 
obavljenog 3. svibnja 1991. u Medicinskom centru Zadar - Služba za patološku anatomiju, koji pokazuju da je poginuli zadobio „strijelnu ranu vratne kičmene moždine” i da je uzrok smrti „Conquassatio medullae spinalis cervicalis”, te da je istoga dana u 11 sati obavljeno vađenje krvi, a u 11:30 uzimanje mokraće. Analiza alkohola u krvi i mokraći provedena je 28. svibnja 1991. u Centru za kriminalistička ispitivanja i vještačenja MUP-a RH na temelju uzoraka zaprimljenih 9. svibnja 1991., a na osnovi rezultata obavljenih analiza zaključeno je „da je u trenutku smrti imenovani bio trijezan”.

Reakcije na događaje od 2. svibnja 1991.

Nakon ubojstva trinaestorice hrvatskih policajaca u Borovu Selu i Polači 2. svibnja 1991. sigurnosno-političko stanje u Hrvatskoj dramatično se pogoršalo. Toliki gubici izazvali su revolt većine hrvatskih građana. Prema informacijama novinara Večernjega lista, na Narodni trg u Zadru odmah nakon saznanja o ubojstvu Franka Lisice slilo se „više desetaka tisuća ljudi” jer su se Bibinjcima koji su došli prosvjedovati u Zadar pridružili stanovnici grada. Njima su se obratili zastupnici Hrvatskoga sabora Petar Šale, Davor Aras i Drago Krpina, pri čemu su, među ostalim, pozivali ljude neka ne razbijaju svoj grad. ${ }^{66}$

O suradnji Službe kriminalističke policije PU zadarske sa službenicima Policijske postaje Benkovac u otkrivanju počinitelja ubojstva u Polači u benkovačkoj općini u spomenutom službenom spisu nema podataka. No, na temelju pisanja zadarskoga tjednika Narodni list može se zaključiti da ona nije bila korektna. Naime, u izdanju od 18. svibnja, u članku „Naredba o nadležnosti policijskih postaja”, navedeno je da se benkovačka policija ponaša krajnje nekorektno u kriminalističkoj obradi slučaja ubojstva Franka Lisice te da prikriva počinitelje toga zločina iako je benkovačkoj stanici policije poznata grupa koja je to izvela. ${ }^{67}$

Zbog nemogućnosti dijaloga s pobunjenim Srbima, ne samo u konkretnom primjeru nego i općenito, u pokušaju nalaženja načina za mirno rješenje krize i poštovanja hrvatskoga Ustava i zakona, ministar unutarnjih poslova RH Josip Boljkovac prenio je naredbom od 15. svibnja 1991. poslove javne sigurnosti s policijskih postaja Titova Korenica, Gračac i Donji Lapac na PU Gospić, s policijskih postaja Benkovac i Obrovac na PU Zadar i s Policijske postaje Knin na PU Šibenik. ${ }^{6} \mathrm{U}$ pravnom smislu, nakon odluke o formiranju

trakom”, kao i da je od navedenog oružja i streljiva „izuzeto i dostavljeno Centru za krim. ispitivanje i vještačenje 1 trenutna mina, 1 tromblonska mina i jedna ručna improvizirana bomba i nekoliko komada raznih kalibara municije” (FRANKO LISICA, KD „UBOJSTVO”, 02.05.1991.g, brdo Štrkovača kod Polače, Policijska uprava zadarska - Služba kriminalističke policije; Broj: KU-80/91).

${ }^{66}$ E. R. TOMAN, „Poginuo policajac”, Večernji list, 3. 5. 1991., 5.

${ }^{67}$ M. MARIJAČIĆ, „Naredba o nadležnosti policijskih postaja”, Zadarski list, 18. 5. 1991., 4.

68 „SUP Krajine van zakona”, Borba (Beograd), 17. 5. 1991., 8; MARIJAN, Domovinski rat, 74. 
SUP-a Krajine 4. siječnja 1991. i odluke vodstva SAO Krajine u Kninu da na tom području prestaju vrijediti ingerencije MUP-a $\mathrm{RH},{ }^{69}$ to je bila konačna potvrda da su spomenute policijske postaje u SAO Krajini nelegalne, a da je "Martićeva milicija” paravojna formacija.

I vukovarsko-vinkovačko područje od tada je bilo „u stanju ni rata ni mira”: „sela naseljena Srbima u vukovarskoj i vinkovačkoj općini od tada su bila u stanju otvorene pobune, a sela s većinskim Hrvatima adekvatno su odgovorila." ${ }^{70}$ Kakvo je stanje na vukovarskom području zavladalo nekoliko dana nakon 2. svibnja 1991. opisuje i rečenica: „Područje je ulazilo u ratno življenje, potpunu nesigurnost, otežanu opskrbu najosnovnijim prehrambenim artiklima, iskapčanja struje i vode." ${ }^{11}$

Upravo je stvaranje kaosa i nekontroliranoga stanja u Hrvatskoj bio cilj „velikosrpskih” stratega jer bi to bio povod za uvođenje „izvanrednoga stanja” i intervenciju JNA u Hrvatskoj. Ipak, hrvatska vlast uspjela je nadzirati situaciju i ne dopustiti eskalaciju sukoba, no nije mogla osigurati javni red i sigurnost na području pod nadzorom pobunjenih Srba jer je djelovanje hrvatske policije već od kolovoza 1990. onemogućavala JNA, uz prijetnju oružanim sukobom. Time je JNA otvoreno preuzela ulogu zaštitnika i saveznika pobunjenih Srba u Hrvatskoj.

Na vijest o ubojstvu hrvatskih policajaca u Borovu Selu i Polači odmah je sazvana i održana sjednica Vrhovnoga državnog vijeća $\mathrm{RH}$, nakon čega se predsjednik Republike Franjo Tuđman preko televizije i radija obratio „hrvatskom narodu i svim građanima Hrvatske":

„Doživjeli smo najtragičniji dan u kratkoj povijesti demokratske vlasti, nakon jedva jednogodišnje pobjede mlade demokracije u Hrvatskoj. Suočeni smo sa, mogao bih reći, početkom otvorenog rata protiv Republike Hrvatske.

Taj tragični događaj nije došao iznenadno. Mi smo suočeni svu godinu od uspostave hrvatske demokracije, nove vlasti, s pokušajem izazivanja građanskog rata, oružane intervencije, s pokušajem obaranja hrvatske vlasti i suzbijanja suvereniteta Republike Hrvatske, kojeg je ona navijestila usvajanjem svog novog Ustava. A posljednjih dana te namjere i ti događaji očitovali su se u maltretiranju, u fizičkom i psihičkom teroru stanovnika sela Kijeva, zatim u mučkom ubojstvu redarstvenika u Polači, zatim u ranjavanju dvojice policajaca i odvođenju petorice ljudi iz sela Potkonja, napokon, došlo je do zarobljavanja dvojice hrvatskih policajaca u Borovu Selu kraj Vukovara i onda do najtragičnijeg događaja - do pogibije dvanaestorice redarstvenika kada su pokušali osloboditi dvojicu zarobljenih svojih drugova policajaca u Borovu Selu.

\footnotetext{
${ }^{69}$ „Odluka o osnivanju Sekretarijata za unutrašnje poslove SAO Krajina i Rešenje o imenovanju sekretara za unutrašnje poslove SAO Krajina”; Izvješće - Ustavni sud RH 2002., 13.

${ }^{70}$ MARIJAN, Obrana i pad Vukovara, 62.

${ }^{71}$ D. VESELČIĆ, „Barikade u selima”, Večernji list, 6. 5. 1991.; MARIJAN, Obrana i pad Vukovara, 63.
} 
Sve to govori da smo suočeni s veoma rasprostranjenom i razrađenom akcijom četničkih i velikosrpskih elemenata od Knina do istočnih sela Slavonije da rašire odmetnički pokret, da izazovu oružanu intervenciju Armije, da spriječe promjene na vrhu Jugoslavije u Predsjedništvu, da onemoguće raspisani referendum s kojim bi i hrvatski narod i svi građani Hrvatske mogli izraziti svoju volju, svoju demokratsku odlučnost o tome na koji način žele izaći iz postojeće društveno-političke krize današnje Jugoslavije.

Koristim ovu prigodu da se obratim Srbima u Hrvatskoj, istakao je dr. Tuđman u svojoj izjavi, onima koji nisu na strani odmetništva, da se ograde od tih nasilnika i terorističkih akcija, jer te akcije, to odmetništvo, to narušavanje ustavno-pravnog poretka Republike Hrvatske dovodi, zapravo, u pitanje normalan suživot srpskog pučanstva s hrvatskim pučanstvom, dovodi, znači, u pitanje i njihovu sadašnjost i budućnost, i za očekivati je da će se onaj glas koji se već do sada čuo od razboritih Srba u Hrvatskoj, da će se čuti u još jačoj mjeri i da će oni sami onemogućiti u svojim redovima one elemente koji zaista dovode u pitanje normalan suživot $i$ sređivanje prilika koje su na štetu Hrvatske, u cjelini i Jugoslavije, a koje ne može trpjeti ni Europa." 72

Zbog pogibije policajaca u Borovu Selu i Polači u Hrvatskoj su 3. svibnja sve zastave na državnim ustanovama bile spuštene na pola koplja, a 4. svibnja bio je dan žalosti. ${ }^{73}$

Ubrzo nakon krvoprolića u Borovu Selu i Polači, 6. svibnja 1991. dogodilo se ubojstvo vojnika JNA makedonskoga podrijetla Sašo (Saško) Gešovskog prilikom prosvjeda tisuća građana protiv JNA ispred zgrade u kojoj je bilo zapovjedništvo tadašnje Vojnopomorske oblasti Jugoslavenske ratne mornarice u Splitu. Prosvjed je organiziran zbog toga što je JNA u blokadi držala selo Kijevo, u kojem je osnovana ispostava hrvatske policije. ${ }^{74}$

Nakon sukoba i krvoprolića 2. svibnja 1991. te zbog demonstracija protiv JNA u Splitu 6. svibnja, u kojima je poginuo jedan vojnik JNA, Štab Vrhovne komande Oružanih snaga SFRJ podignuo je borbenu spremnost JNA i mobilizirao dio postrojbi. Prema zapažanju Davora Marijana, „početkom svibnja na krizna područja Hrvatske uvedena su tri nova bataljuna, oklopni iz 51. mehanizirane brigade (mbr) iz Pančeva u Petrinju, mehanizirani 36. mbr iz Subotice u Vinkovce i mehanizirani 453. mbr iz Srijemske Mitrovice u Vukovar. Pokušaj dovođenja 10. motorizirane brigade JNA iz Mostara u Split nije uspio jer su ga 7. svibnja 1991. u mjestu Polog kod Širokog Brijega spriječili hercegovački Hrvati, pa je ona razmještena na području Kupresa. JNA je zaposjela i dva

\footnotetext{
${ }^{72}$ KRMPOTIĆ, Kronologija rata, 55.

73 „Dan žalosti 4. svibnja”, Vjesnik (Zagreb), 4. 5. 1991., 5.

${ }^{74} \mathrm{O}$ okolnostima ubojstva Saše (Saška) Gešovskog postoje razne verzije. Svoje sjećanje na taj događaj dali su njegovi neposredni sudionici: vojnik JNA Toni Stojčev (Slobodna Dalmacija /Split/, „Spektar”, 26. 1. 2019., 4) i tadašnji potpredsjednik Skupštine općine Split Marin Mihanović (Slobodna Dalmacija, „Spektar”, 2. 2. 2019., 6-7).
} 
mosta na Dunavu, kod Iloka i Bezdana, koja su osiguravale kopnene snage i snage Riječne ratne flotile. Tim su potezima stvorene pretpostavke za uvođenje novih snaga JNA u Hrvatsku". ${ }^{75}$

Zbog svih tih događaja i u Beogradu se na nekoliko sjednica saveznih tijela, na kojima su sudjelovali i predstavnici republika, pregovaralo o smirivanju stanja. ${ }^{76} \mathrm{Na}$ proširenoj sjednici Predsjedništva SFRJ održanoj od 7. do 9. svibnja 1991., prema podacima iz knjige Davora Marijana, dogovoreno je da se odmah spriječi „kretanje oružanih formacija i naoružanih građana u kriznim žarištima, izuzev legalnih lokalnih organa unutrašnjih poslova, a između područja sa pretežno srpskim stanovništvom i ostalih delova Hrvatske, u oba pravca, svih naoružanih formacija i grupa, izuzev jedinica JNA i SSUP”. Na temelju izvora Marijan je zaključio da je „ograničenje planirano na mjesec dana, a za provedbu je zadužena JNA"77 te da su "pobunjeni Srbi i hrvatska policija tretirani na isti način, s tim da se snagama SUP-a Knin nije smjelo dopustiti kretanje na teritoriji ostalih opština tzv. SAO Krajine" ${ }^{78}$ Prema njegovu mišljenju, „mjere su trebale jamčiti održanje postojećega stanja te tako nisu mogle donijeti nikakav pomak u razrješenju krize, što je odgovaralo srbijanskomu čelništvu. Prihvaćene zadaće i dalje su bile u skladu s postupanjem JNA, koja je praktično legalizirala snage koje je prije dovela na krizna žarišta mimo suglasnosti Predsjedništva SFRJ odnosno bez suglasnosti ili znanja dijela njegovih članova. Ona je postupno demobilizirala mobiliziranu pričuvu i spustila podignuti stupanj bojne spremnosti”. ${ }^{79}$

Odluke Predsjedništva SFRJ donesene na spomenutoj proširenoj sjednici - na kojoj je zapravo pravno omogućeno, odnosno legalizirano dotadašnje nelegalno raspoređivanje JNA izvan vojarni, ali i omogućeno daljnje raspoređivanje JNA na područja sukoba srpskih terorista i hrvatskih policijskih snaga - Borisav Jović u svojem je dnevniku pod datumom 9. svibnja 1991., iako uz oprez da je možda riječ i o „taktičkom kompromisu Hrvatske”, trijumfalistički prikazao kao „vojnu opciju”:

„Sednica je trajala dva dana i dve noći 7. i 8. ovog meseca. Završili smo 8. maja posle ponoći, u stvari 9. maja ujutro u 3 časa. Ta je sednica bila izuzetno teška i dramatična. Podela je bila potpuna, nesloga velika, ali i presija da je vojna opcija neminovna ako se ne postigne politički sporazum. [...] Imajući u vidu neviđeno političko nadmudrivanje i natezanje koje je trajalo dva dana i dve noći, mora se imati u vidu da su ovi zaključci možda i taktički kompromis Hrvatske, koja je bila

${ }^{75}$ MARIJAN, Slom Titove armije, 253-256; MARIJAN, Domovinski rat, 73.

${ }^{76}$ MARIJAN, Domovinski rat, 73.

77 Zapisnik sa 119. sednice članova Predsedništva SFRJ, održane 7-9. maja 1991. godine, preuzeto iz: MARIJAN, Domovinski rat, 73.

${ }^{78}$ SVA MORH, Komanda 5. VO: I uprava GŠ OS SFRJ, Izvod pov. br. 881-1 od 16. 5. 1991., preuzeto iz: MARIJAN, Domovinski rat, 74.

79 JOVIĆ, Poslednji dani SFRJ, 324; MARIJAN, Slom Titove armije, 420, 423; MARIJAN, Domovinski rat, 74. 
do krajnjih granica 'priterana uza zid'. U svakom slučaju zaključci predstavljaju ogroman napredak u pogledu ovlašćenja koja su data vojsci... [...] Slobodan [Milošević, op. a.]) smatra da bi bilo dobro suziti front otpora time što bismo pustili Slovence da izađu. Ako republike nemaju na to primedbi, treba omogućiti Slovencima da se legalno odvoje. [...] Rekao sam da je sada aktuelno ostvarivanje odluka Predsedništva SFRJ od 7. i 8. maja, koje su legalna podloga za aktivnosti JNA i svih drugih za rešavanje problema. [...] U suštini, odluka Predsedništva SFRJ je vojna opcija (jer je dala ogromna ovlašćenja vojsci) iako se tako ne zove." ${ }^{\text {S0 }}$

\section{Zaključak}

Spomenuti događaji već su dijelom obrađeni u historiografiji, no zbog činjenice da je ubojstvo 12 policajaca u Borovu Selu znatno zastupljenije u literaturi od događaja u Polači nametnula se potreba da se u istom članku spomenu oba događaja da bi se upozorilo na njihovu važnost, ali i na važnost datuma 2. svibnja 1991. u kronologiji novije hrvatske povijesti. Stoga su, radi doprinosa raspravama o počecima Domovinskoga rata u Hrvatskoj, u radu navedeni izvori koji do sada nisu detaljno prezentirani u historiografiji, a posebice se to odnosi na izvore o ubojstvu hrvatskoga policajca Franka Lisice u Polači, koji su prvi put javno predstavljeni.

Krvoproliće počinjeno 2. svibnja 1991. nad hrvatskim policajcima na dva različita mjesta, u dvije regije $\mathrm{RH}$, Slavoniji i Dalmaciji, pokazuje da terorističke aktivnosti srpskih ekstremista nisu bile izolirani incident nego dio politike izazivanja oružanoga sukoba na područjima na kojima su Srbi živjeli u znatnijem broju i koja su pobunjeni Srbi smatrali dijelom „srpskoga teritorija”. Istodobno ti događaji pokazuju da je dotadašnje terorističko djelovanje srpskih ekstremista preraslo u novu etapu obračuna s predstavnicima hrvatske vlasti, u kojoj su ubojstva policajaca trebala poslužiti za izazivanje dublje krize, odnosno za uvođenje izvanrednoga stanja u državi, čime bi se onemogućio proces stvaranja samostalne hrvatske države. Jednako tako, nakon 2. svibnja 1991. postalo je jasno da će se ratni sukob teško izbjeći.

Sličnost obaju događaja jest u tome što su hrvatski policajci ubijeni iz zasjede, čime su srpski ekstremisti hrvatskoj vlasti poslali poruku da neće moći mirno ostvariti kontrolu nad područjem samoproglašene SAO Krajine, odnosno područja koje će oni po svaku cijenu pokušati zadržati u dotadašnjoj Jugoslaviji, u zajednici sa Srbima iz Srbije i BiH. Spomenuti događaji izazvali su reakciju Hrvata i zaoštravanje situacije na vukovarskom i zadarskom području, na kojem je hrvatska vlast morala pojačati prisutnost policijskih snaga. Dakako, spomenuti događaji izazvali su i reakciju JNA i jugoslavenskoga predsjedništva.

${ }^{80}$ JOVIĆ, Poslednji dani SFRJ, 320-323. 
Ubojstvom 13 hrvatskih policajaca istoga dana - dvanaestorice u Borovu Selu u Slavoniji i jednoga u Polači u Dalmaciji - srpski teroristi ubili su i nadu $\mathrm{u}$ mirno rješenje krize u RH te potvrdili spremnost da svoje političke zahtjeve izbore ratom. Istodobno su krvoprolića u Borovu Selu i Polači te ubojstvo vojnika Saše (Saška) Gešovskog 6. svibnja 1991. u Splitu bili povod za sazivanje proširene sjednice Predsjedništva SFRJ od 7. do 9. svibnja 1991., na kojoj su vodstvo Srbije i JNA primorali hrvatsko vodstvo na prihvaćanje odluka kojima su legalizirane dotadašnje i buduće aktivnosti JNA na teritoriju RH i pripreme za provođenje vojne opcije, odnosno za uvođenje snaga JNA u Hrvatsku. Ubojstva 13 hrvatskih policajaca 2. svibnja 1991. bila su zlokobna najava rata, odnosno velikosrpske agresije na Hrvatsku.

\section{Izvori}

Borba (Beograd), 1991.

Duga (Beograd), 1990.

HR-HDA-UPRH: Hrvatska, Hrvatski državni arhiv, Zagreb, Ured predsjednika Republike Hrvatske.

HR-HMDCDR-8, 9. K JNA: Hrvatska, Hrvatski memorijalno-dokumentacijski centar Domovinskog rata, Zagreb, fond 8, 9. korpus Jugoslavenske narodne armije.

„Izvješće u povodu inicijative Vlade Republike Hrvatske, klasa: 004-01/0202/12, ur. broj: 5030109-02-2 od 10. listopada 2002. godine”. Ustavni sud Republike Hrvatske (predsjednik Suda, dr. sc. Smiljko Sokol), broj: U-X-2271/2002, Zagreb, 12. studenog 2002.

Narodna armija (Beograd), 1991.

Narodne novine (Zagreb), 56 (1990), 31 (1991).

NIN, (Beograd) 1989.

Novosti (Beograd), 1990.

Politika (Beograd), 1990.

Republika Hrvatska, Ministarstvo informiranja. Dossier: Knin (veljača 1990 / veljača 1991.), Zagreb, veljača 1991.

Republika Hrvatska, Ministarstvo unutarnjih poslova (dopis br. 511-01-4122093-1990.). Informacija o događajima u nemirima obuhvaćenim općinama Republike Hrvatske, 7. studenog 1990.

Slobodna Dalmacija (Split), 2019.

Službeni vjesnik Like, broj 12/90.

Službeni vjesnik općina Drniš, Knin i Šibenik (Šibenik), broj 12/90.

Večernji list (Zagreb), 1990-1991.

Velika Srbija. Novine Srpske radikalne stranke (Beograd), 1991, 1994.

Vjesnik (Zagreb), 1991. 
Vreme (Beograd), 1991.

Zadarski list (Zadar), 1991, 2010.

\section{Literatura}

BARIĆ, Nikica. „Osnutak i razvoj službe unutrašnjih poslova autonomnih oblasti u Hrvatskoj”. Istorija 20. veka 29 (2011), br. 2: 75-86.

BARIĆ, Nikica. Srpska pobuna u Hrvatskoj 1990. - 1995. Zagreb: Hrvatski institut za povijest; Golden marketing - Tehnička knjiga, 2005.

BRIGOVIĆ, Ivan; MARTINIĆ JERČIĆ, Natko; RADOŠ, Ivan. „Prvi oruŽani napadi na hrvatske redarstvene snage 1991.”. Hrvatski vojnik (Zagreb), br. 498, 22. 4. 2016.

CRAVETTO, Enrico, gl. ur.; GOLDSTEIN, Ivo, gl. ur. hrvatskog izdanja; BARIĆ, Nikica, ur. Povijest - poslijeratno doba 1945. - 1985., knj. 18. Zagreb: Europapress holding, 2008.

CRKVENČIĆ-BOJIĆ, Jasna, ur. Popis stanovništva 1991. Narodnosni sastav stanovništva Hrvatske po naseljima (Dokumentacija 882). Zagreb: Republički zavod za statistiku Republike Hrvatske, 1992.

ĐURIĆ MIŠINA, Veljko, ur. Republika Srpska Krajina - 10 godina poslije. Beograd: Dobra volja, 2005.

Hrvatska policija u Domovinskom ratu. Zagreb: MUP RH, 2011.

JOVIĆ, Borisav. Poslednji dani SFRJ. Izvodi iz dnevnika. Kragujevac: Prizma, ${ }^{2} 1996$.

KADIJEVIĆ, Veljko. Moje viđenje raspada. Vojska bez države. Beograd: Politika - izdavačka delatnost, 1993.

KRMPOTIĆ, Miroslav, ur. Kronologija rata - agresija na Hrvatsku i Bosnu i Hercegovinu (s naglaskom na stradanje Hrvata u BiH) 1989. - 1998. Zagreb: Hrvatski informativni centar, 1998.

MARIJAN, Davor. „Događanja naroda’ u Kninu 1989. godine - slom jugoslavenske ustavne konstrukcije u Hrvatskoj”. Radovi Zavoda za povijesne znanosti HAZU u Zadru (2017), br. 58: 439-467.

MARIJAN, Davor. Domovinski rat. Zagreb: Despot Infinitus; Hrvatski institut za povijest, 2016.

MARIJAN, Davor. Hrvatska 1989. - 1992.: rađanje države. Zagreb: Hrvatski institut za povijest, 2017.

MARIJAN, Davor. Obrana i pad Vukovara. Zagreb: Hrvatski institut za povijest, 2013.

MARIJAN, Davor. Slom Titove armije (JNA i raspad Jugoslavije 1987. 1992.). Zagreb: Hrvatski institut za povijest; Golden marketing - Tehnička knjiga, 2008.

NAZOR, Ante, ur. Grad je bio meta: Bolnica, Dom umirovljenika... (agresija Srbije, odnosno JNA i srpsko-crnogorskih snaga na Republiku Hrvatsku i srpska 
okupacija Vukovara 1991.). Zagreb: Hrvatski memorijalno-dokumentacijski centar Domovinskog rata, 2008.

NOBILO, Mario. Hrvatski feniks. Diplomatski procesi iza zatvorenih vrata 1990. - 1997. Zagreb: Nakladni zavod Globus, 2000.

POPOVIĆ, Srđa. One gorke suze posle. Beograd: Peščanik, 2010.

RADELIĆ, Zdenko; MARIJAN, Davor; BARIĆ, Nikica; BING, Albert; ŽIVIĆ, Dražen. Stvaranje hrvatske države i Domovinski rat. Zagreb: Hrvatski institut za povijest; Školska knjiga, 2006.

RUPIĆ, Mate, ur. Republika Hrvatska i Domovinski rat 1990. - 1995. Dokumenti, knj. 1: Oružana pobuna Srba u Hrvatskoj i agresija oružanih snaga SFRJ i srpskih paravojnih postrojbi na Republiku Hrvatsku (1990. - 1991.). Zagreb: Hrvatski memorijalno-dokumentacijski centar Domovinskog rata, 2007.

RUPIĆ, Mate, ur. Republika Hrvatska i Domovinski rat 1990. - 1995. Dokumenti, knj. 2: Dokumenti institucija pobunjenih Srba u Republici Hrvatskoj (1990. - 1991.). Zagreb; Slavonski Brod: Hrvatski memorijalno-dokumentacijski centar Domovinskog rata; Hrvatski institut za povijest, Podružnica za povijest Slavonije, Srijema i Baranje, 2007.

ŠETIĆ, Nevio. Ostvarenje suvremene hrvatske države. Pula: Sveučilište Jurja Dobrile u Puli; Geaidea, 2013.

VUČUR, Ilija. „Pogibija Gorana Alavanje 23. studenog 1990: događaj, interpretacije, manipulacije”. Časopis za suvremenu povijest 49 (2017), br. 3: 587609.

ŽUNEC, Ozren. Goli život. Socijetalne dimenzije pobune Srba u Hrvatskoj, sv. I-II. Zagreb: Demetra, 2007.

\section{Internetski izvori}

„Obilježavanje obljetnice policijske ispostave Pridraga”. Ministarstvo unutarnjih poslova RH, Policijska uprava zadarska, 28. 4. 2010. Pristup ostvaren 14. 12. 2018. http://zadarska.policija.hr/MainPu.aspx?id=39788.

„Otkrivena spomen ploča bivše Policijske ispostave Stankovci”. Ministarstvo unutarnjih poslova RH, Policijska uprava zadarska, 1. 4. 2010. Pristup ostvaren 14. 12. 2018. http://zadarska.policija.hr/MainPu.aspx?id=37823. 


\section{SUMMARY}

\section{The Murders of Croatian Policemen on 2 May 1991 - Heralding the Greater Serbian Aggression on Croatia}

2 May 1991 holds a special place among the dates in the chronology of the Croatian War of Independence. It cannot be ignored because it is the date of an event that significantly influenced the further flow of events in Croatia. On that day, in Borovo selo near Vukovar in Slavonia and in Polača near Zadar in Dalmatia, 13 Croatian policemen were killed in an ambush, which significantly worsened the already complex security and political situation in Croatia. In order to understand the circumstances (historical context) of the mentioned murders, this work will briefly refer to the causes of the collapse of the Socialist Federal Republic of Yugoslavia and the beginning of the democratisation process in Croatia after the multiparty elections in April and May 1990, show some of the reactions of Serb extremists to the mentioned process that preceded the 2 May 1991 murders, and the reactions of the Croatian authorities and the Presidency of Yugoslavia, i.e. the leadership of Serbia and the Yugoslav People's Army, to the mentioned event. Namely, after the mentioned bloodshed, the Yugoslav Presidency reached the decision on its session of 7 to 9 May 1991 to legally allow, actually legalise, the use of the Yugoslav People's Army in Croatia, officially to prevent further conflict. The mentioned murders, which should also be observed in the context of rebel Serb attempts in Croatia to provoke a reaction of the Yugoslav People's Army and introduce a state of emergency, pushed Croatia into a period where there was neither war nor peace. Actually, 2 May 1991 signalled that the chances for the peaceful resolution of Croatian-Serbian disputes in Croatia were getting smaller.

Key words: Serb rebellion; Croatian War of Independence; Greater Serbian politics; 2 May 1991; Borovo selo; Polača; murders of Croatian policemen 